\title{
Lightning Interactions with Humans and Lifelines
}

\author{
A. Kalair, N. Abas and N. Khan ${ }^{*}$
}

Department of Electrical Engineering, COMSATS Institute of Information Technology, Park Road, Islamabad, Pakistan

\begin{abstract}
Lightning is one of the fascinating phenomena exhibiting tremendous natural power. It is source of awe, curiosity, enticement, inspiration as well as fear. On average, 50 lightning strikes occur on earth in one second. Fortunately not all of them kill people, albeit $10 \%$ people fall prey to lightning annually, out of which hardly 20 to $25 \%$ die. Lightning injures victims by heat, shockwave, intense brightness, radio waves, and secondary slip or fall mechanisms. Lightning injury is different from the normal electric shock as it involves transient flashover unlike the electrical contact freeze, wherein alternating (AC) and direct currents (DC) pass through the conductive interior body. Vacuity in knowledge is the driving force behind discoveries and inventions. Lightning experts had hardly developed any concurrence on lightning physics, and the observation of dark lightning complicated the Gordian knot. Lightning preventive, alerting and control devices help reduce fatality rates by the bolts out of blue skies. Lightning was considered to be the second cause of death making natural disasters after flashfloods but preventive measures have slithered it down to the third place in developed countries. Lightning prevention rule recommends 'when the thunder roars, go indoors'. This work describes lightning characteristics, damage thresholds to humans, machines, energy infrastructures, airplanes, wind turbines, light railway tractions, underground cables and pipelines. Power and energy lifelines such as transmission lines, oil tankers and gas or petroleum pipelines are susceptible to lightning strikes. Artificial rocket and laser triggered lightning protection and control techniques help to divert the lightning attacks. Interaction of lightning with power and energy infrastructures disrupts these lifelines. However, lightning itself is viewed as an extraterrestrial energy source. Lightning energy harvesting is an interesting application which has been investigated quantitatively.
\end{abstract}

Keywords: Lightning, damage threshold, prevention, control, energy lifelines.

\section{INTRODUCTION}

Lightning is a spectacular phenomenon which has been a source of awe, curiosity, inspiration, and fear for centuries. Lightning is often viewed as life creating phenomenon. Concussive forces behind the brilliance and thunder of lightning serve as themes for religion, superstition, transcendence, and modern science. Lightning harms living animals on its way by heat, sound and brilliancy. Outside none is safe from lightning, as adage goes, when it roars go indoors. Antediluvian civilizations used to regard lightning as manifestation of their deities. Romans in $700 \mathrm{BC}$ purported lightning as a tool of vengeance and condemnation. They used to refuse burial rituals to sinners struck by lightning. The temple of Zeus, the Greek god of thunder and lightning, still today stands in Alexandria. Aristotle thought that lightning resulted from ignition of telluric fumes forming clouds. Socrates supposed that lightning was caused by a vortex of air. Greek and Romans knew lightning mostly strikes on high objects therefore they used to worship at hill top sites to appease their lightning gods. Roman emperors were known to wear laurel wreaths and sealskin to ward off lightning strikes. Thales of Miletus in $600 \mathrm{BC}$ observed induction of charges attracting feathers and straws when an amber rod was rubbed with a dried

*Address correspondence to this author at the Department of Electrical Engineering, COMSATS Institute of Information Technology, Park Road, Islamabad, Pakistan; Tel: +92 -51 -9247000-3; Fax: +92-51- 9247006;

E-mail: nasrullahk@yahoo.com material, which is considered as the first experiment of electricity. Sir William Gilbert in 1600 AD coined the word "electrica" derived from Greek word electron. The world electricity, as we use today, was first time coined by Sir Thomas Browne in 1646. Saundro Volta invented the first electrochemical battery supplying constant electricity in $1700[1,2]$.

Benjamin Franklin carried out his famous kite experiments in June 1752 on a rainy cloud to demonstrate the lightning as a discharge of static electricity [3]. Man has taken too long to recognize the treasure of fossil fuels and electricity, below the feet and above the head ever since. Discovery of crude oil in 1959 and invention of internal combustion engine in 1960s marked the beginning of the second industrial revolution after steam engine. Electrostatic generators were common in $1800 \mathrm{~s}$, but the first direct current (DC) distribution system was launched by Edison in 1882, followed by alternating current (AC) power systems by Nicolas Tesla and Westinghouse in 1880s. Development in electrical instrumentation for utility and photographic techniques for silver screen in 1890s helped Pockel measure AC/DC voltages, currents and electromagnetic fields associated with lightning discharges. Human race remained unaware of electricity and black gold for thousands of centuries, although the lightning was overhead and fossil fuels underneath. Our future dear ones might wonder on our minimalism after discovery and invention of new technologies like engine and electricity in the $19^{\text {th }}$ century. Technical reinforcements and positive feedbacks in various industries helped understand nature to end myths, 
superstitions, misconceptions and fairy tales. Despite the prevalent information and communication age, many of us are still unaware of lightning nature even in developed countries [4]. We know the lightning consists of transient unidirectional impulsive static charge which is neither DC nor AC electricity. Experience shows 50 or $60 \mathrm{~Hz} \mathrm{AC}$ is relatively more dangerous than $\mathrm{DC}$ and static atmospheric electricity. Magnitude of tolerable DC voltage is higher than $\mathrm{AC}$ and lightning causes flashover outside human body [5].

Lightning is a natural atmospheric discharge phenomenon that occurs between earth and clouds, among oppositely charged clouds during cumulonimbus and nimbostratus. Lightning discharges are also observed during tornados, snowstorms and volcanic eruptions [6]. It may occur in streak, sheet, ribbon, bead and ball forms [7]. Most of wildfires incidents are caused by rainless dry lightning. Normal forked bright thundering bolts between clouds and earth are called streak lightning. It is an enthralling incident but exaggerative media reports have imprinted a concussive image in civil society. Nearly 70 to $90 \%$ lightning strikes occur between clouds and hardly 10 to $30 \%$ between clouds and earth. Lightning strikes earth over 100 times per second (average 8 millions per day) yet electrocution chances are in fact quite rare. Nearly 60 to 150 people die due to lightning incidents every year in Pakistan yet more than $60 \%$ cases go unreported. According to reports of National Oceanic and Atmospheric Administration (NOAA) from 1959 to 1994, the lightning is responsible for 3,000 deaths and 10,000 causalities in United States of America (USA), which may actually be more than above due to lack of reporting. A lightning event occurs in 0.1-0.8 $\mathrm{ms}$ under potential difference of $1-2 \times 10^{9}$ volts, causing $10 \mathrm{kA}$ to $200 \mathrm{kA}$ current impulses between clouds and ground over distances of 2 to 3 miles. A thunder may be heard 12 miles away but its heat lightning may be seen 100 miles away. Cloud to cloud lightning crawlers (spider lightning) can travel over 35-75 miles but it turns deadly if it strikes ground. A few millimeters sized lightning plasma channel in air appears to be brighter than the sun. A lightning flash is a concurrent interaction of complex multiple steps, which is not completely understood even today. By far we safely define lightning as a positive or negative current of approximately $30 \mathrm{kA}$ (50\% probability), that has an approximate frequency range from a few $\mathrm{Hz}$ to $1 \mathrm{MHz}$, with a minimum current value of approximately $9 \mathrm{kA}$ and a maximum current value of approximately $400 \mathrm{kA}$. Positive lightning currents are much higher than negative lightning strikes. Sample pictures recorded by NOAA, American ground and satellite- based UV, visible, IR and X-rays detectors and cameras based lightning images are shown in Fig. (1).

When electric potential on clouds exceeds air insulation threshold, the lightning starts in 30 to $50 \mathrm{~m}$ long spurts of static energy. After the first segment springs out, the cloud refills the channel to repeat and retreat until voltage falls below the air breakdown threshold, or lightning flash occurs between cloud and ground depleting cloud borne charges. Clouds above the ground induce opposite charge on earth. Downward leaders may join the upward streamers to complete the lightning channel. A return stroke gushes out of earth to fill all the branches to make lightning visible. Multiple upward current streamers arise but all of them may not meet downward leaders to complete lightning channel yet they have enough energy to harm. Worldwide 50,000 thunderstorm may cause forest fires, injuries to animals (and humans), damage to electrical appliances, electronic controllers and communication equipment. Lightning strikes kill people, inflict financial and downtime business losses to industries. Electric traction systems like, Malaysian LRT, face electronic components damage losses worth millions of dollars each year. Lightning strike attracts to tall, isolated and pointy objects in air. A mountain top half a mile away, a TV tower 300 yards far or a tree 75 yards away under the 30 to $50 \mathrm{~m}$ radius area under the last branch point is outside the protection zone. Landline phones and metal pipes bring home the remote lightning [8]. There are little data on the distribution of severity of lightning injuries among the struck population, which can serve as a topic worth researching.

Lightning strikes create radio waves in $3 \mathrm{kHz}$ to $10 \mathrm{MHz}$ range of the spectrum. Lightning signatures allow their detection world-wide. Distant lightning shortwave may be detected in 2 to $7 \mathrm{MHz}$ band. If you listen after $3 \mathrm{AM}$ to 3 $\mathrm{MHz}$ you will hear sound of tiny bells ringing together. UHF TV signals reflect the lightning pathways by tuning 200 to 300miles distant UHF TV station at 475.75 MHz. Professor Martin Uman, a well known lightning expert in University of Florida, proposed to measure small radio waves created by cosmic rays on their way to earth through clouds that could allow measurement of lightning initiation electric fields

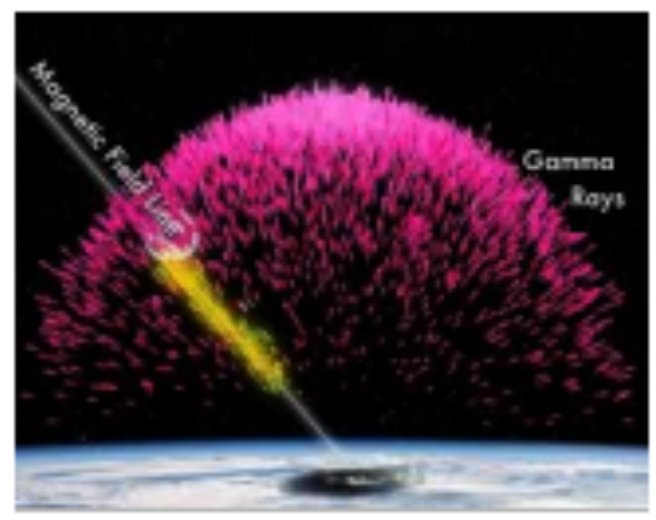

a. Dark lightning

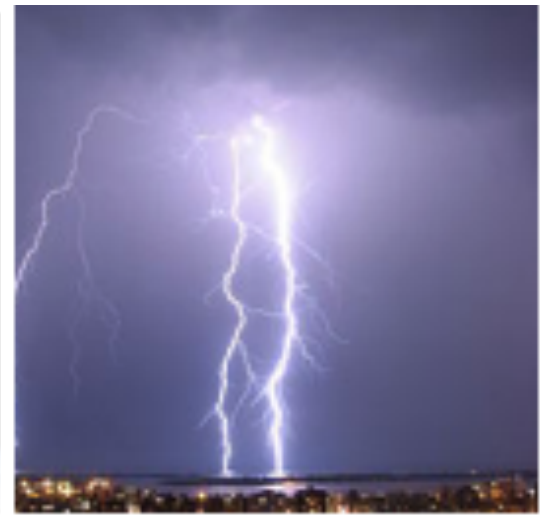

b. Bright lightning

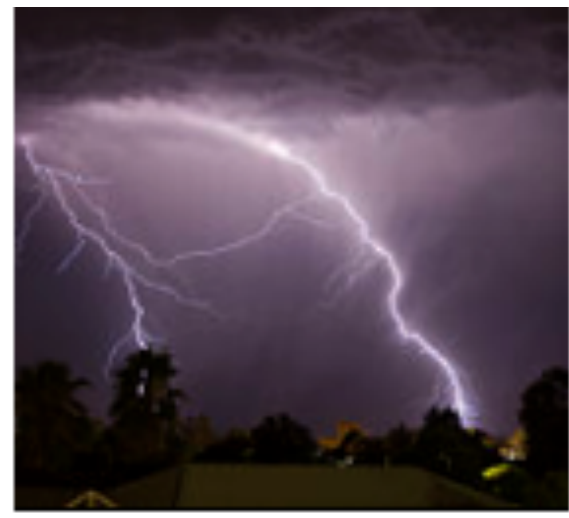

c. Dry lightning

Fig. (1). Spectacular dark, bright and dry lightning (Credit NASA, USA). 
pockets on clouds. Balloon method can not help measure electric field well inside clouds. Cosmic rays constantly rain down on earth. They can be used as probes to detect cloud borne electric fields. A giant natural particle accelerator above thunder clouds may be established by collision of cosmic rays with air molecules stripping off electrons, which accelerate due to electric fields to form energetic particle beams. Ahmad Kalair observed a dark thin vertical beam on 2 August 2013 at 11:17 PM. This dark vertical line emanating from earth to clouds was also witnessed by the co-authors at 11:20 to 11:27 which persisted long time up to 4:30AM next day. Real picture (a), edited (b), and next day actuality are shown in Fig. (2).

It appeared like a dark beam opposite to laser beam at first sight. It was visible at certain locations with changing sharpness and contrast like destructive part of some interference pattern over remote city lights background. It subtended over 20 degree angle on eye between earthy background and top clouds. We tried hard to capture by 8 Mega Pixel Apple i-Phone but could not record it. Over ten persons saw it again and again but could not understand the underlying physics. We discussed with experts who doubted it to be the shadow of some ground-based object in front of bright light. We can imagine a similar scene by a parabolic dish antenna have floodlight instead of detector. Due to peaking solar cycle the sun is emitting strong cosmic rays which may cause a vertical accelerator producing electron beam by stimulated absorption of light. AIM, CHIBIS and Firefly satellites are recording data on the particle accelerator. Here objective is not to support pseudo science (which this phenomenon could be) rather to share observation with scientific community. This information was shared on internet with experts who doubted it to be shadow of some ground-based object on foggy cloudy background. One of the coauthors observed a rising light above clouds during clouds to ground lightning over Kashmir Valley at night from passenger aircraft heading from Singapore to Lahore near New Delhi, India in 2003.

A lightning event by lower electric field exceeding air breakdown threshold might cause invisible lightning but it can not generate ionizing radiations. Researchers have noted $\mathrm{x}$-ray and gamma-ray bursts by satellite-borne detectors. Earlier theorists predicted possibility of X-ray emissions in 1925 but could not prove it. Normal lightning may be visible or invisible but does not produce ionizing radiations. UF/FIT researchers reported observation of X-rays using sodium iodide detectors during artificial wire-trailing rocket triggered lightning. University of Florida (UF) and Florida Institute of Technology (FIT) claim observation of X-rays from stepped leaders of natural lightning. Lightning comes down in "stepped and dart leaders" and completes return stroke by upward streamers. Lightning strokes between cloud and ground may be depicted as periodically fired arrows, an inferno missile launched by earth. Researchers believe a silent phenomenon called dark lightning occurs just before the start of visible lightning. Satellite data records show the X-ray and gamma-ray bursts signature appear just at the start of lightning. After observation of dark lightning phenomenon the researchers theorize whether dark lightning may be the initiating impulse for visible lightning [9]. Dark lightning may be viewed as an ionizing radiation scattering explosion in clouds preceding the observation of natural lightning. Gamma rays cause dark lightning to emit X-rays which may be used to investigate lightning processes [10]. Joseph Dwyer (FIT) explains dark lightning as rapid electrons and positrons avalanche breakdown discharge within clouds causing $\mathrm{x}$-rays emission before conventional white lightning.

Sometimes cloud to-air and cloud top to ground positive lightning strikes occur. Clouds are normally positively charged on upper and negatively charged on lower sides. Upsides down may occur on moving thunder head to cause a bolt from blue sky. Cloud to-air lightning may take the form of cloud to-ground lightning ahead of an approaching thunderstorm which is known as a blue out of the blue sky. A positive giant bearing $200 \mathrm{kA}$ current may hit the ground from storm's top anvil up to 20 miles away. Lightning may be linked to the inset of headache and migraines.

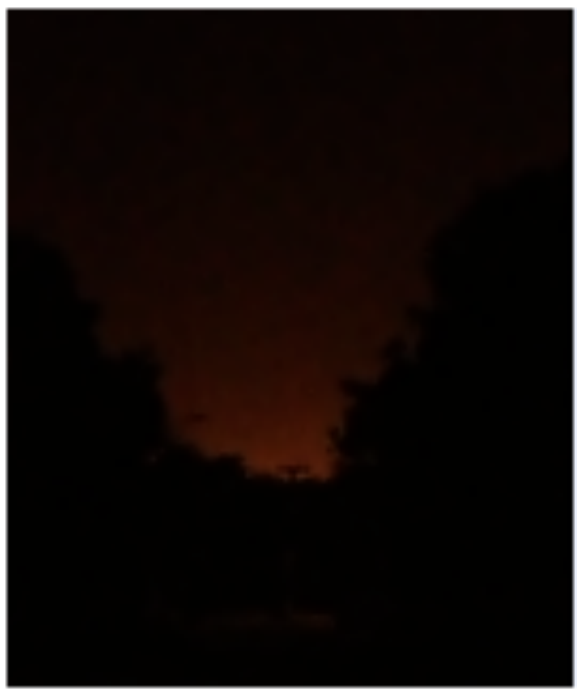

a. Real picture

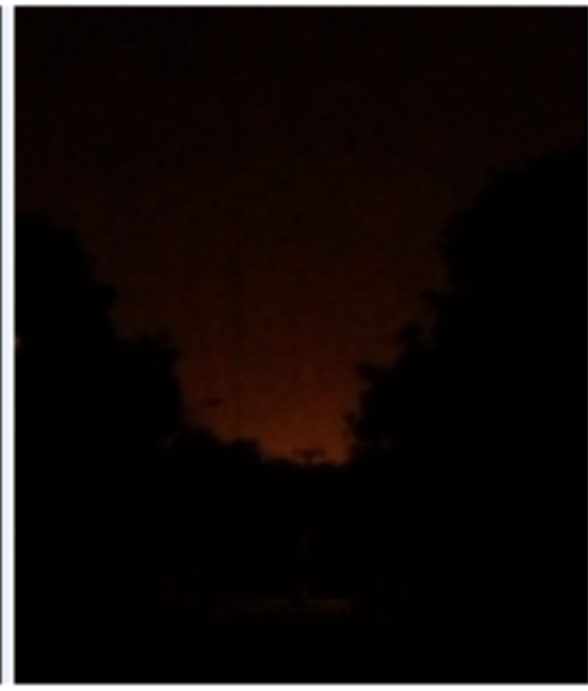

b. Actual (edited a)

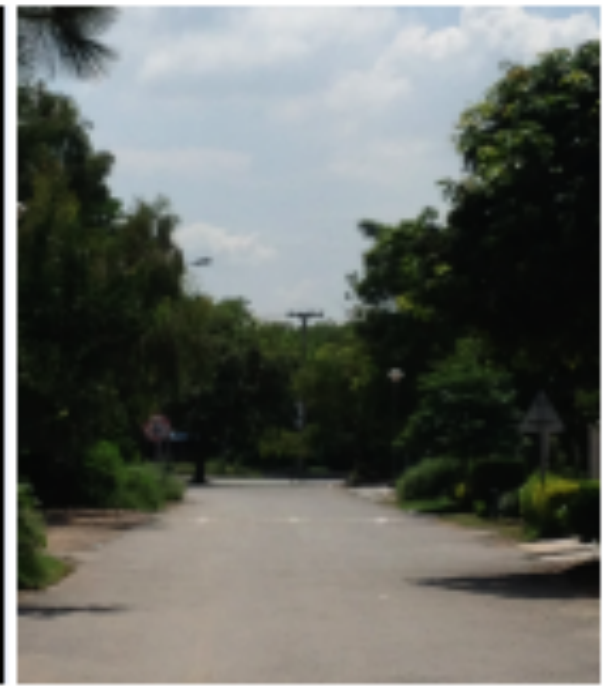

c. Next day scene

Fig. (2). Observation of a vertical dark line from earth to clouds. 
Researchers report chances of $31 \%$ increased risk of headache and $28 \%$ increased risk of migraine for chronic headache sufferers on days lightning struck within 25 miles. Excluding normal weather effects, a $19 \%$ increased risk of headache on the lightning days has been observed. It is believed that the electromagnetic waves emitted during lightning trigger headache but it has no evidence. If the above reason is taken to be valid, all mobile signals may be accused which creates a great business and social problem. Another hypothesis seemingly stronger than the earlier ones describes that the ozone produced by lightning can cause release of fungal spores which might lead to migraine. Weather conditions, seasonal affective disorder (SAD), may trigger headache but it needs physical basis to justify the claim. Chemical consequence of laser-induced breakdown of gases is another emerging challenge [11]. Lightning-induced shockwaves have been known to have stunning deafening effect on victims.

\section{LIGHTNING CHARACTERISTICS}

Lightning is a form of visible static electric discharge (arc) between a thundercloud and the earth. How rain clouds become charged up to $10 \mathrm{kV} / \mathrm{cm}$ is not fully understood, but most rain clouds are negatively charged at the base and positively charged at the top. The negatively charged leaders, called stepped leader, dip downward in about 100 segments of $50 \mathrm{~m}$ lengthy jumps at a speed of about $100 \mathrm{~km} / \mathrm{s}$ bridging the clouds to earth. It may take hundreds of milliseconds to reach the ground but subsequent dart leaders are 10 times faster than the stepped leader. This initial phase involves a relatively small current and an invisible leader. When the stepped leader is quite close to the ground, a few positive streamers arise from grounded objects to the approaching leader. The stepped leader and the positive streamers meet in the air to cause a short circuit, a return strike, and consequently a much higher current flows. A lightning flash may consist of single or multiple strikes separated by 20 to $60 \mathrm{~ms}$ or an average $30 \mathrm{~ms}$ time intervals. Subsequent return strikes are initiated by the dart leaders, akin to the stepped leader as shown in Fig. (3) [12].

The long duration (500 ms) single-strike (10-100 A) lightning flash may be more dangerous with regard to utility TSS or MOV devices. Continuing currents between lightning flashes make the incidence more energetic. With regard to test electrical power equipment against a lightning threat IEC 61643-1 uses 10/350 $\mu \mathrm{s}$, VDE 0160 uses 100/1300 $\mu \mathrm{s}$, IEEE C62.41.1 uses 10/1000 $\mu$ s test waveforms and recently IEEE Std C62.41.2-2002 uses $100 \mathrm{kHz}$ Ring Wave and the $1.2 / 50 \mu \mathrm{s}-8 / 20$ voltage current combination waves. The specific energy parameter $(\mathrm{W} / \mathrm{R})$ may be calculated using $\int \mathrm{I}^{2} \mathrm{dt}$. Lightning phenomena occurs under such diverse natural weather conditions, and it is hard to predict the times involved in 1 to 40 (average 5-6) lightning flashes occurring in 1-2 s. Every return strike occurring after 40ms needs a fresh start leader. However, the channel loses its ionization in $100 \mathrm{~ms}$. Most (80\%) of the multi-strike events follow the same channel or location but some subsequent strikes may be separated by $0.2-4.5$ miles. This diagram originates from Uman for three strikes of lightning. It is usually applied to the most negative lightning flashes but does not seem plausible for some of the negative and all positive lightning flashes. The main strike travels at a speed of $2-4.9 \times 10^{7} \mathrm{~m} / \mathrm{s}$ within a few tens of $\mu$ s but the peak current decays over several tens of $\mu \mathrm{s}$. Before 1994 the inter-strike time was thought to be $3-15 \mathrm{~ms}$, but recently it was measured to be $<1$ ms [13].
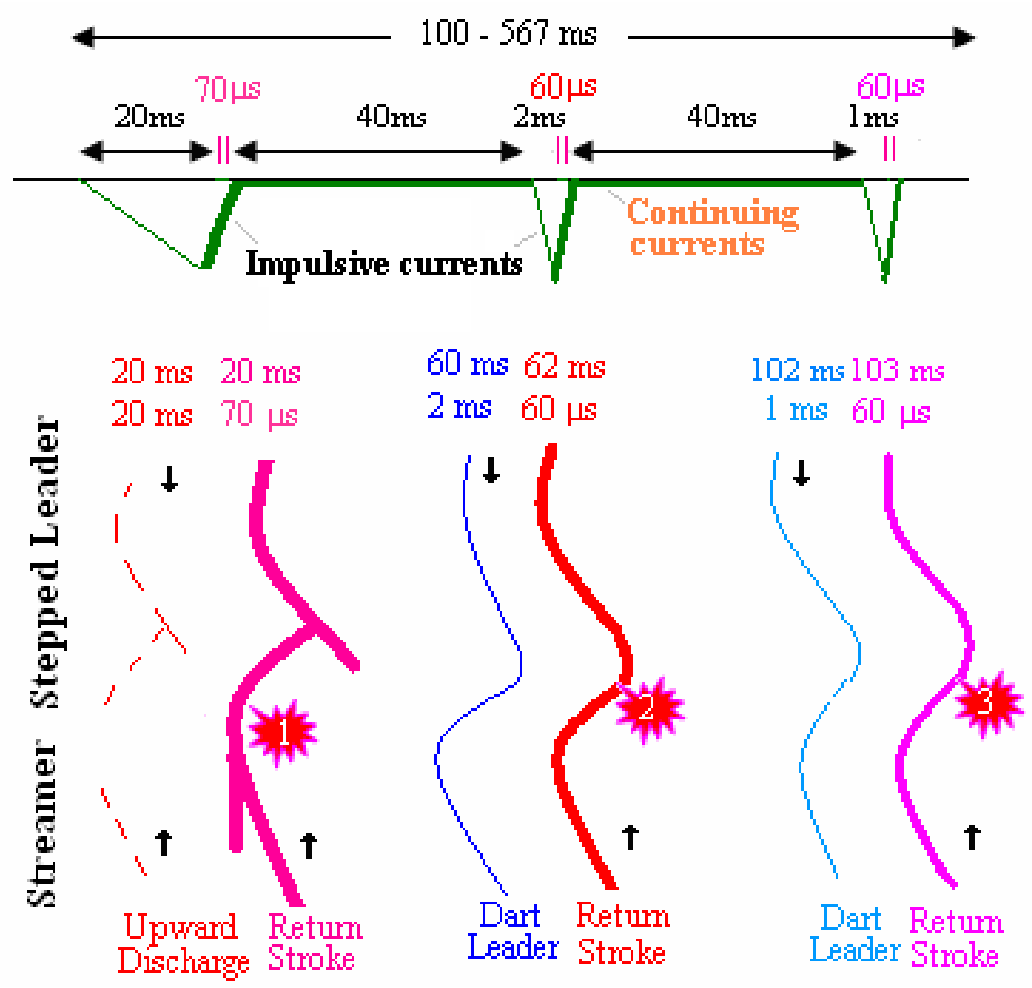

Fig. (3). A lightning flash consisting of four strikes lasting $567 \mathrm{~ms}$. 
The typical lightning impedance is around $1000 \Omega$ and the peak power about $1000 \mathrm{GW}$. The number of strokes per flash may vary from 1 to 30 and the average varies from 3 to 4. Re-strike lightning inter-stroke times are twice compared to first but periods of formation time are much lower due to superheated air channels. Lightning event quickly builds to its peak in $1-10 \mu$ s but decays in 50 to $200 \mu$ s with average fwhm duration of 60 to $70 \mu \mathrm{s}$. The overall flash duration may vary from $100-600 \mathrm{~ms}$ but there are chances of 23 to $31 \mathrm{~ms}$ single stroke events. Positive lightning flashes consist of 1 or 2 strokes. Out of 900, flashes about 780 flashes had an overall duration of $50 \mathrm{~ms}$ and 725 flashes had an average duration of $40 \mathrm{~ms}$. The mean rise time of a strike may vary from 8 to $9 \mu$ s [14]. Large lightning pulses have total pulse duration of about $56 \mu \mathrm{s}$ and FWHM of $26 \mu \mathrm{s}$. According to available data, the number of pulses in first $5 \mathrm{~ms}, 20 \mathrm{~ms}, 80$ $\mathrm{ms}$ and total flash duration are 4, 6, 8 and 9 respectively [1518]. Uman's group developed lightning gas dynamics, EM, distributed circuits and engineering models to calculate electric and magnetic fields of lightning and associated currents $[19,20]$. Some researchers have recently reported lightning parameters using high speed video observations [21]. The lightning parameters may be measured using Rogowski coils and shunt resistance techniques [22]. The correlation between the lightning current and luminosity does not remain unchanged during a flash even for a pulse. Luminosity in ascending stage is lower than that in descending stage for a pulse [23]. In an independent study, 62 negative stepped leaders, 76 negative dart leaders and 29 positive leaders were recorded and analyzed using highspeed cameras operating at frame rates ranging from 1,000 or 11,800 frames per second. The speed of positive leaders showed a clear tendency to increase whilst that of negative dart leaders to slow down when they approach ground [24].

The average thunder-storm (cumulonimbus at an elevation of 4-5 miles) moves at a speed of $25 \mathrm{mph}$. There are more than three million lightning flashes worldwide per day, or about 40 flashes per second. Normally it can be seen as a single lightning bolt but it also occurs in the form of a ball, ribbon, sheet, or string of beads. Lightning not only occurs on earth but also on other planets such as Venus, Jupiter, and Saturn. The basic studies on lightning parameters were conducted by earlier researchers $[15,25-$ 27]. Weidman [28] improved further lightning parametric studies and also started time resolved and spectral analysis of the lightning spectrum in the range of $850-1400 \mathrm{~nm}$. Orvile $[29,30]$ also started daytime lightning photography and reported a slight current variation with the altitude of the clouds. A typical lightning bolt may transfer $10^{20}$ electrons in a few $\mu$ s causing a peak current of about $100 \mathrm{kA}$. Most lightning current measurements range from 5 to $20 \mathrm{kA}$ but more than $200 \mathrm{kA}$ have also been reported. The total earth charge around $10^{6} \mathrm{C}$ and the potential between earth and the electro-sphere is $300-500 \mathrm{kV}$. A continuous current of 1 $\mathrm{pA} / \mathrm{m}^{2}$ flows from a $50 \mathrm{~km}$ elevation $(\mathrm{E}=100 \mathrm{~V} / \mathrm{m})$ to the earth uniformly. Lightning recharges the earth by transferring electrons. The lightning energy is produced by solar energy. According to Rakov and Uman [31], the lightning current usually ceases within $1 \mathrm{~ms}$ for a given strike, but sometimes there is a continuing current of the order of $100 \mathrm{~A}$ following one or more of the strikes [28]. The temperature of lightning may be in range of $10,000{ }^{\circ} \mathrm{C}$. Lightning parameters for engineering calculations and fatality risks calculations are shown in Table 1.

Lightning flashes continue to occur within clods (IC), cloud to cloud (CC) and cloud to ground (CG). Global average lightning flashes ratio of intra-cloud plus cloudcloud to cloud-ground ( $\mathrm{IC}+\mathrm{CC}: \mathrm{CG}$ ) is $75: 25$. This ratio is 90:10 in tropics and 50:50 at $60^{\circ}$ latitudes. There is no lightning activity at poles. During ground to cloud lightning flashes are also noted above the clouds in addition to blue jets and red sprites with blue tentacles. Lightning flashes are not evenly distributed around the planet earth [33]. Majority of thunderstorms appear in tropics resulting $70 \%$ of lightning flashes occur there. Ocean surfaces receive the fewest lightning strikes. Lightning frequency has been recorded from 2004 to 2005 to be $158 / \mathrm{km}^{2}$ in Kifuka village in eastern mountains of Democratic Republic of the Congo, which is the highest lightning density in the world. Lightning flash frequency is also very high in Venezuela, Brazil, Singapore, Malaysia, and Florida of USA. Flash Lightning Flatland region in Brazil and Lightning Alley territory in USA [34] are well known for high lightning frequencies. Earlier NOAA estimated global lightning frequency to be $50-100$ times a second, $4.32-8.64 \times 10^{6}$ a day, or $1.57-3.15 \times 10^{9}$ a year, but later NASA and NADSA joint LIS satellite study measured it to be 39-49 times a second, 3.37-4.23 $\times 10^{6}$ a day, or $1.23-1.55 \times 10^{9}$ a year [35]. According to latest NOAA information 18,111,343 flashes occurred in 2012 in USA but only 13 persons died in 2013 (January-June). From 1997 to 2012 (15 years), total 22.849 billion flashes were recorded giving an average frequency of $1.523 \times 10^{9}$ flashes per year [36]. America had started several ground and satellite-based programs to measure and record lightning in US and worldwide. A space- based lightning image sensor (LIS) was launched in 1997, optical transient detector (OTD) started in 1995 and ended in 2000, ground-based national lightning detection network (NLDN), long range lightning network (1200 miles) was started in 1996, field mill data based TRMM LSB ended in 1999, space based LDAR and field mill data based KSC was started in 1997 and ended in 2008, advanced ground-based data network continues in Florida to measure electric field strength, satellite-based lightning mapper sensor (LMS) records global discharges and operational line-scan system (OLS) monitors global lightning activities.

\section{LIGHTNING INTERACTIONS}

Lightning strikes randomly interact with humans, animals, airplanes, wind turbines and light rail transits (LRT). After electric grid and tall towers, the wind turbines and LRTs on ground and airplanes or birds in atmosphere are potential victims of thunder clouds. All American aircrafts face more than one lightning incidence per year but they are well protected to endure lightning strikes [37]. A wind turbine in CIIT solar park got damaged by lightning within six months of its operation. Worldwide $36 \%$ wind turbines are damaged by lightning every year. The LRTs suffer heavy electronic component damages in Malaysia, Japan and Philippines. Aircrafts use static lightning dischargers, wind turbines and LRT use AC and DC lightning arresters. Wind turbine is a relatively new technology which needs special lightning design procedures normally not available in older standards. Normal aircraft accidents occur by human 
Table 1. Typical CG Lightning Flash Parameters [18, 32]

\begin{tabular}{|c|c|c|c|c|}
\hline \multirow{2}{*}{ Names } & \multirow{2}{*}{ Parameters } & Average & Possible & \multirow{2}{*}{$\frac{\text { Typical }}{\text { Based on Others }}$} \\
\hline & & \multicolumn{2}{|c|}{ Based on Uman Measurements } & \\
\hline Stepped leader & $\begin{array}{c}\text { Step-length } \\
\text { Steps interval } \\
\text { Velocity } \\
\text { Charge } \\
\text { Voltage }\end{array}$ & $\begin{array}{c}50 \mathrm{~m} \\
50 \mu \mathrm{s} \\
150 \mathrm{~km} / \mathrm{s} \\
5 \mathrm{C} \\
1 \times 10^{6} \mathrm{~V}\end{array}$ & $\begin{array}{c}3-200 \mathrm{~m} \\
30-125 \mu \mathrm{s} \\
100-2600 \mathrm{~km} / \mathrm{s} \\
3-20 \mathrm{C} \\
1 \times 10^{6}-1 \times 10^{8} \mathrm{~V}\end{array}$ & $\begin{array}{c}60-80 \mathrm{~m} \\
50-60 \mu \mathrm{s} \\
120 \mathrm{~km} / \mathrm{s} \\
10 \mathrm{C} \\
1 \times 10^{8}-1 \times 10^{9} \mathrm{~V}\end{array}$ \\
\hline Dart leader & $\begin{array}{l}\text { Velocity } \\
\text { Charge }\end{array}$ & $\begin{array}{c}2000 \mathrm{~km} / \mathrm{s} \\
1 \mathrm{C}\end{array}$ & $\begin{array}{c}1000-21,000 \mathrm{~km} / \mathrm{s} \\
0.2-6 \mathrm{C}\end{array}$ & $\begin{array}{c}0.9-1 \times c \\
2-3 \mathrm{C}\end{array}$ \\
\hline Return stroke & $\begin{array}{c}\text { Velocity } \\
\text { di/dt } \\
\mathrm{t}_{\text {peak }} \\
\mathrm{t}_{\text {half peak }} \\
\text { Peak current } \\
\text { Charge } \\
\text { Channel length } \\
\text { Channel dia }\end{array}$ & $\begin{array}{c}80,000 \mathrm{~km} / \mathrm{s} \\
10^{6} \mathrm{kA} / \mathrm{s} \\
2 \mu \mathrm{s} \\
40 \mu \mathrm{s} \\
-10-20 \mathrm{kA} \\
2.5 \mathrm{C} \\
5 \mathrm{~km} \\
2 \mathrm{~cm}\end{array}$ & $\begin{array}{c}20-160 \times 10^{6} \mathrm{~m} / \mathrm{s} \\
<1->80 \times 10^{6} \mathrm{kA} / \mathrm{s} \\
<1-30 \mu \mathrm{s} \\
10-250 \mu \mathrm{s} \\
-110 \mathrm{kA} \\
0.2-20 \mathrm{C} \\
2-14 \mathrm{~km} \\
\text { Size of thumb }\end{array}$ & $\begin{array}{c}\text { Decays in } 100 \mathrm{~ms} \\
300 \times 10^{6} \mathrm{kA} / \mathrm{s}(+\mathrm{ve}) \\
1.8-2.5 \mu \mathrm{s} \\
30 \mu \mathrm{s} \\
-200 \mathrm{kA} \\
300 \mathrm{C}(+\mathrm{ve}) \\
1500-7000 \text { feet } \\
0.1 \mathrm{~m}\end{array}$ \\
\hline Lightning flash & $\begin{array}{l}\text { No. of strokes } \\
\text { Stroke interval } \\
\text { Flash duration } \\
\text { Charge } \\
\text { Magnetic field }\end{array}$ & $\begin{array}{c}3-4 \\
40 \mathrm{~ms} \\
0.2 \mathrm{~s} \\
25 \mathrm{C} \\
1000 \mathrm{G}\end{array}$ & $\begin{array}{c}1-40 \\
3-100 \mathrm{~ms} \\
0.01-2 \mathrm{~s} \\
3-90 \mathrm{C} \\
900-1100 \mathrm{G}\end{array}$ & $\begin{array}{c}5-6 \\
1-500 \mathrm{~ms} \\
1-500 \mathrm{~ms} \\
300 \mathrm{C}(+\mathrm{ve})\end{array}$ \\
\hline Channel & $\begin{array}{c}\text { Temperature } \mathrm{K} \\
\text { Temperature C } \\
\text { Temperature F } \\
\text { Length } \\
\text { Electron }(\rho)\end{array}$ & $\begin{array}{c}30,000 \\
10,000 \\
18,000 \\
5 \mathrm{~km} \\
\ldots \ldots \ldots\end{array}$ & $\begin{array}{c}24,000-40,000 \\
8,000-16,000 \\
15,000-60,000 \\
\ldots \ldots \ldots \ldots \\
\ldots \ldots \ldots \ldots . . .\end{array}$ & $\begin{array}{l}\text { Hotter than sun } \\
20,000 \\
50,000 \\
6 \text { miles } \\
10^{23}-10^{24} \mathrm{e} / \mathrm{m}^{2}\end{array}$ \\
\hline Graupel & Super-cooling & $-10-20{ }^{\circ} \mathrm{C}$ & Negative ${ }^{\circ} \mathrm{C}$ & $10 \mathrm{kV} / \mathrm{cm}$ \\
\hline Lightning types & $\begin{array}{l}\text { Negative } \\
\text { Positive }\end{array}$ & $\begin{array}{l}-120 \mathrm{kA} \\
+300 \mathrm{kA}\end{array}$ & $\begin{array}{c}-20-120 \mathrm{kA} \\
+30-+300 \mathrm{kA}\end{array}$ & $\begin{array}{c}138-250 \mathrm{KWh} \\
84000 \mathrm{KWh}\end{array}$ \\
\hline Lightning energy & $\begin{array}{c}\text { Negative } \\
\text { Positive (rare) }\end{array}$ & $\begin{array}{l}5 \times 10^{8} \\
3 \times 10^{11}\end{array}$ & $\begin{array}{l}1 \times 10^{5}-1 \times 10^{8} \\
1 \times 10^{7}-1 \times 10^{13}\end{array}$ & $\begin{array}{l}100 \mathrm{~W} \text { bulb/0.25Yr } \\
100 \mathrm{~W} \text { bulb/100Yrs }\end{array}$ \\
\hline Lightning effects & $\begin{array}{l}\text { Can measure } \\
\text { Occurrence }\end{array}$ & $\begin{array}{l}6 \mathrm{~km} \\
2 \mathrm{~km}\end{array}$ & $\begin{array}{l}1.2-12.5 \text { miles away } \\
0-4.5 \text { miles around }\end{array}$ & $\begin{array}{l}3-4 \text { miles } \\
500 \mathrm{~m}\end{array}$ \\
\hline Total Energy dissipated $100 \mathrm{~kJ} / \mathrm{m}$ & $\begin{array}{c}\text { Visible } \\
\text { Sound } \\
\text { Heat } \\
\text { Radio waves }\end{array}$ & $\begin{array}{c}2 \\
35 \\
35 \\
28\end{array}$ & $\begin{array}{c}1-3 \\
10-50 \\
10-50 \\
10-50\end{array}$ & $\begin{array}{c}\text { Based on data } \\
\text { http://FusEdWeb.llnl.gov/CPEP/ }\end{array}$ \\
\hline
\end{tabular}

mistakes or structural failures during whirling anvil $\mathrm{CB}$ clouds. Aircrafts in fact trigger short circuit of charged clouds, and therefore the large aircrafts are more susceptible than smaller aircrafts. Passengers onboard often see flash and hear thunder but sometimes crew too remains unaware of lightning incidence. Lightning flashes on humans, animal, tree, wind turbine, airplanes and LRT are shown in Fig. (4).

Lightning occurs on electric grids, power houses, transmission lines, communication towers, high rising towers like Eiffel Tower in France, and Twin tower in Malaysia. View of lightning on quarter mile high tower inspires scientists but frightens visitors. It is like seeing big alive sharks behind a thick glass in sea submerged stations.
Lightning damages billion dollar equipment, life and property losses worldwide every year. Optical ground wires (OPGW) were used on high voltage lines to increase telecom capacity but it is a priority victim of lightning strike [38]. LRT is another victim of lightning strikes [39]. The overhead contactor system transferring power from live line to train is primary victim of lightning strike. Malaysian LRT suffers million dollars loss every year. Aircraft in atmosphere is not safe from lightning during landing and take-off. Surge protection devices such as static charge wicks provide adequate protection to aircraft compared to mobile on ground LRT, which may fall prey to several kilometer remote lightning incidence via its own track. 

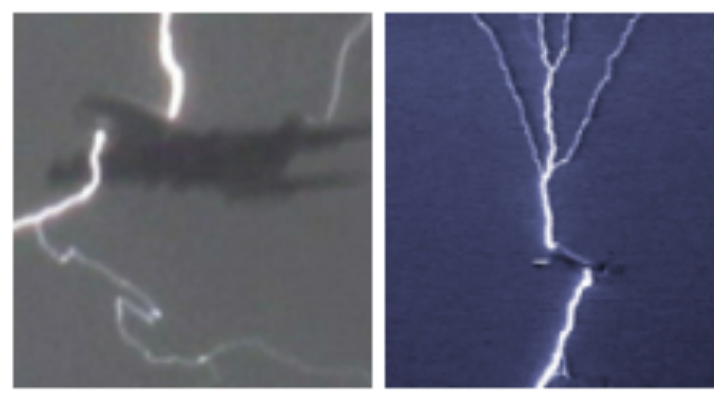

a. Cloud to aircraft lightring
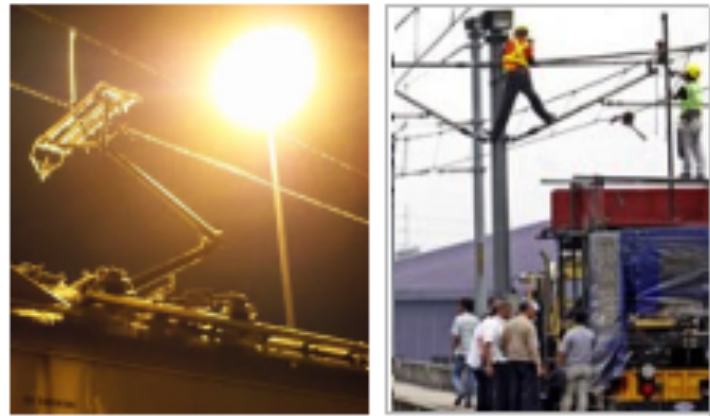

c. Lightning struck LRTs
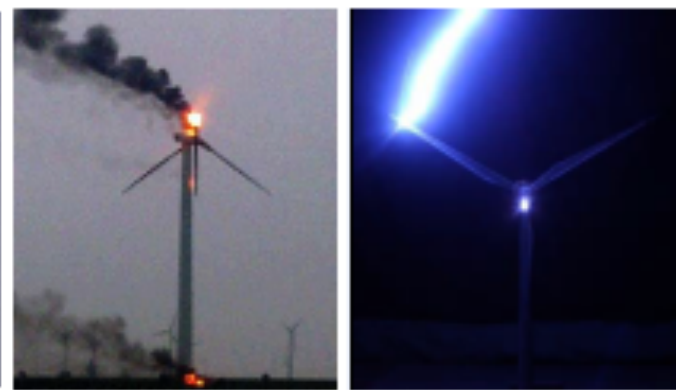

b. Cloud to wind turbine lightning
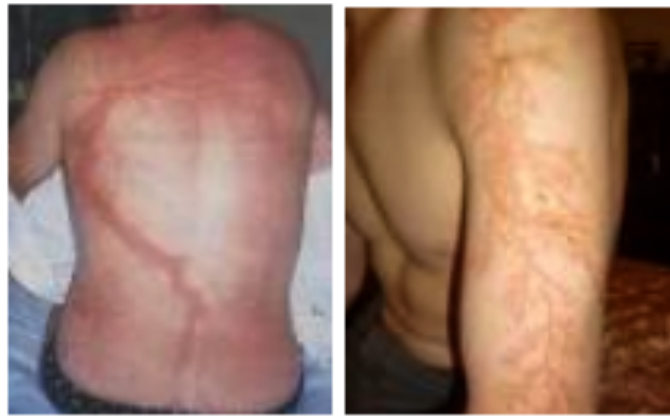

d. Lightning survivor's injuries

Fig. (4). Lightning strikes on (a-) aircrafts, (b-) wind turbines, (c-) LRT, and (d-) humans (Credit:http://metro.co.uk; http://www.crh.noaa.gov; www.brookingsregister.com, http://www.Philstar.com; http://phnewsupdate.blogspot.com/) \& Victims.

\subsection{Lightning-Human Interactions}

Human fatalities are caused by amount of current not voltage. Van De Graff generator produces million volts without any current. Walking across carpet in room may cause $12 \mathrm{kV}$ potential. We often observe sparks on blanket whilst sleeping due to high static voltage but it causes no harm. We generally perceive electric tinge for $\mathrm{I}<10 \mathrm{~mA}$, feeble jolt for $10-20 \mathrm{~mA}$ without losing muscle control. A $10 \mathrm{~mA} \mathrm{AC}$ may cause muscle contraction (let go threshold) of young man. Our muscles loose voluntary control during 20-75mA electric shock for contact freeze (let-go-threshold). Experts believe $30 \mathrm{~mA} \mathrm{AC}(60 \mathrm{~Hz})$ or $300-500 \mathrm{~mA} \mathrm{DC}$ shocks have the same effect of fibrillation. Ventricular fibrillation occurs when $75-100 \mathrm{~mA}$ current passes through our body and death may occur for $100-200 \mathrm{~mA}$ current. Over $200 \mathrm{~mA}$ severe burns, muscle contraction and wide range of serious damage occur. Electrical injury depends upon voltage, tissue resistance, duration and path of current flow, magnitude and type of current. Injury severity depends upon Joule's heat energy $\left(\mathrm{W}_{\mathrm{e}}\right)$ given by;

$\mathrm{W}_{\mathrm{e}}=\mathrm{I}^{2} \times \mathrm{R} \times \Delta \mathrm{T}$

Heat energy required for drilling a hole in mass $m$ with specific heat $\mathrm{C}$ and heat of fusion $\mathrm{H}_{\mathrm{f}}$ is given by;

$\mathrm{W}_{\text {th }}=\mathrm{C} \times \mathrm{m} \times \Delta \mathrm{T}+\mathrm{m} \times \mathrm{H}_{\mathrm{f}}$

From (1) and (2), the minimum exposure time $\Delta \mathrm{T}$ may be estimated; as

$$
\Delta T=m H_{f} /\left(I^{2} R-C \times m\right)
$$

Critical body current below the ventricular fibrillation threshold may be given by Dalziel's formula [40]
$\mathrm{I}_{\mathrm{CR}} \leq \mathrm{k} \Delta \mathrm{T}^{0.5}$

where $\mathrm{k}$ varies from 0.065 to $0.165 \mathrm{As}^{0.5}$ and $\Delta \mathrm{T}$ is shock duration. Critical value of the electric charge $\left(\mathrm{Q}_{\mathrm{CR}}\right)$ may be estimated by Ossyypka's formula [41].

$\mathrm{Q}_{\mathrm{CR}}=0.1 \mathrm{~A} \mathrm{~s}$

An electric shock involving $100 \mathrm{~mA}$ current for 10 seconds may impart $0.1 \mathrm{C}$ which leads to ventricular fibrillation but lightning flash contains hundreds of coulombs.

Flow of arm to arm and arm to foot currents cause macroshock due its passage through heart. Sometimes microshocks may occur due to pace maker, guide wire or conducting catheters. Assuming human body resistance of $800 \Omega(400$ to $1200 \Omega$ ) from head to feet and dangerous energy $\mathrm{W}_{\mathrm{d}}(=30 \mathrm{~J})$, the mean specific energy $\mathrm{W}_{1 \Omega}$ capable of causing death may be given by [42].

$\mathrm{W}_{1 \Omega}=\mathrm{W}_{\mathrm{d}} / \mathrm{R}_{\mathrm{h}}=30 / 800=0.0375 \mathrm{~J} / \Omega$

For the most optimum situations, for $\mathrm{R}_{\mathrm{h}}=400 \Omega$ and $\mathrm{W}_{\mathrm{d}}$ $=50 \mathrm{~J}, \mathrm{~W}_{1 \Omega}$ is $0.125 \mathrm{~J} / \Omega$. A person with $1000 \Omega$ body resistance may get $125 \mathrm{~J}$ but its probability is too low. Berger assumed for $1000 \Omega$ body with 1000 A current the voltage drop from head to feet becomes $1000 \mathrm{kV}$ causing external flashover in air. The arc on human body would be $2 \mathrm{~m}$ long with electric gradient $20 \mathrm{~V} / \mathrm{cm}$. Flashover arc limits the potential difference from head to feet to $4 \mathrm{kV}$ and current to 4 A. Amount of overall electric energy imparted by lightning to human body may be estimated by [43]

$\mathrm{E}=\mathrm{V} \times \mathrm{I} \times \Delta \mathrm{T}=4000 \times 4 \times 0.5 \times 10^{-3}=8 \mathrm{~J}$ 
It is below the lower limit of the critical threshold energy for ventricular fibrillation cardiac arrest. Situation may sometime change due to nonlinear skin insulation.

Many victims survive direct strike as most of charge is dissipated in air through arc. A lightning flash may consist of 3 to 4 (maximum 30) strokes separated in time by 40 to 50 $\mathrm{ms}$. Overall flash time may be average $500 \mathrm{~ms}$. Energy content in a typical negative flash for $30 \mathrm{kA}$ current and $15 \mathrm{C}$ charge may be 500 MJ. A positive lightning flash with 120 $\mathrm{kA}$ current and $350 \mathrm{C}$ charge may be $2000 \mathrm{MJ}$ [44]. Electric chair used to use 700 to $2200 \mathrm{~V}$ potential and 6 to $12 \mathrm{~A}$ current for 30 to 90 seconds to electrocute criminals as punishment in some of western countries in past. Electric chair threshold energy used to be $200 \mathrm{~J}$ but multiple times higher energy was used, perhaps, to minimize the pain time. It is commonly believed that electric shock imparting 10-50 J energy into human body can cause ventricular fibrillation [45]. When a victim is struck by direct lightning stroke his death probability is an important question which needs clear answer. Human body hand to hand resistance for $50 \mathrm{~Hz} \mathrm{AC}$ electricity varies with voltage level.

Skin dielectric breakdown occurs at 450 to $600 \mathrm{~V}$. Wet skin has little lower resistance. A voltage of 500 to $1000 \mathrm{~V}$ may cause internal burn. Direct flash death probability might be once in 2000 years. During side flash spark jumps over person in contact with object struck with lightning. Human body may have $1.5 \mu \mathrm{H} / \mathrm{m}$ inductance, which under $18 \mathrm{kA} / \mu \mathrm{s}$ current intensity cause $54 \mathrm{kV}$ potential. During contact voltage or side flash (splash) the lightning energy dissipated in human body $\left(\mathrm{W}_{\mathrm{h}}\right)$ and object under strike $\left(\mathrm{W}_{\mathrm{l}}\right)$ may be distributed according to their resistances

$\mathrm{W}_{\mathrm{h}} / \mathrm{W}_{1}=\mathrm{R}_{\mathrm{l}} / \mathrm{R}_{\mathrm{h}}$

If $\mathrm{R}_{1}<\mathrm{R}_{\mathrm{h}}$ then $\mathrm{W}_{1}>\mathrm{W}_{\mathrm{h}}$ which leads to bypass of lightning energy [42]. This criterion may be good for lightning to a copper rod side flash but may not be acceptable for side flash with tree or water pipes. Copper rod earth resistance may be $1 \Omega$ but that of tree may be several ohms. Normal iron objects like pipes have quite a few ohms resistance. Lightning impulse rises to its peak value in $1.9 \mu$ s and then decays over tens of $\mu$ s. Actual build up time may vary from 1 to $10 \mu \mathrm{s}$ [18]. The probability of flashover is higher for 1.9 $\mu$ s during which lightning energy transferred to human body may be given by

$\mathrm{W}_{\mathrm{h}}=\mathrm{V}^{2} \times \Delta \mathrm{T} / \mathrm{R}_{\mathrm{h}}=(54000)^{2} \times 1.9 \times 10^{-6} / 800=7 \mathrm{~J}$

Electrical appliances are tested against lightning endurance (ANSI C62.41) using 1.2/50 $\mu$ s and $8 / 20 \mu \mathrm{s}$ voltage and current profiles [46]. Near death animals response may be tested using impulse generators for greater human cause. When lightning voltage reaches $10 \mathrm{kV} / \mathrm{cm}$ strength on human head, it starts flashing over skin. Effective peak voltage collapses due to harmonic distortion. Arc gradient in blowing air is $20-150 \mathrm{~V} / \mathrm{cm}$ due to longer curvy path [47]. During flashover the voltage across head to feet of victim may be estimated by

$$
\begin{aligned}
& \mathrm{V}_{\mathrm{h}-\mathrm{f}}=\mathrm{E}_{\text {arc }}(\mathrm{V} / \mathrm{cm}) \times \mathrm{H}(\mathrm{cm})=20 \times 170=3.4 \mathrm{kV} \\
& \mathrm{I}_{\mathrm{h}-\mathrm{f}}=\mathrm{V}_{\mathrm{h}-\mathrm{f}} / \mathrm{R}_{\mathrm{h}}=3400 / 800=4.25 \mathrm{~A} \\
& \mathrm{~W}=\mathrm{V}_{\mathrm{h}-\mathrm{f}} \times \mathrm{I}_{\mathrm{h}-\mathrm{f}} \times \Delta \mathrm{T}_{\mathrm{ms}}=3400 \times 4.25 \times 0.5 \times 10^{-3}=7.23 \mathrm{~J}
\end{aligned}
$$

It is below the fibrillation threshold $(10 \mathrm{~J})$, which means there is least probability of death due to direct hits. If we ignore skin flashover then the $900 \mathrm{kV}$ head to ground potential, assuming $700 \Omega(300-5000 \Omega)$ body resistances, may cause $1.3 \mathrm{kA}$ current for at least $1.9 \mu \mathrm{s}$. Skin flashover reduces head to ground potential to about 3.4 to $4 \mathrm{kV}$ that causes 5 A current for each 60 to $70 \mu$ s stroke imparting 0.04 $\mathrm{J}$ energy through the interior body. Human body may be subjected to over $1 \mathrm{kA}$ current for 0.5 to $1.5 \mu \mathrm{s}$, which can impart $450 \mathrm{~J}$ followed by 4 to $5 \mathrm{~A}$ current for $50 \mathrm{~ms}$. Lightning may cause $1.5 \mathrm{kV}$ step voltage around lightning strike. Soil resistivity of $1 \mathrm{k} \Omega / \mathrm{m}$ may cause $1.5 \mathrm{~A}$ current through legs imparting $45 \mathrm{~J}$ energy during $20 \mathrm{~ms}$ side flashes [48]. During lightning flashes the voltage declines to $50 \%$ of peak in 1 to $2 \mu \mathrm{s}$ (even lower) and current rises exponentially. Arcing phenomenon usually have $41.1 \%$ voltage total harmonic distortion (THD) which tears apart the peak into smaller peaks reducing overall severity.

Immobile trees are more frequent victims of lightning strikes compared to humans and animals. Some types of trees like pine, birch, fir and larch are more frequently struck by lightning incidences. Severity of lightning incidence depends upon weather conditions. Tree damages may be categorized as simple bark loss due to shockwave, wood loss due to fluid heating and complete shatter due to explosive fluid steaming. Minor lightning shockwave strips of leaves and branches. Average intensity lightning heats up sump water causing dehydration. A severe lightning attack converts tree moisture into steam causing explosive smash. Lightning flash leaves traces of physical processes on tree and soil therefore it may be used as reverse engineering to explore the mechanism of natural lightning. A recent study of 37 trees found 37\% loose bark, 11\% wood, $8 \%$ life but $1 \%$ survive minor lightning attacks [49]. An other study of 1000 fir trees in past showed $1 \%$ are completely demolished, $10 \%$ severely damaged from tops, $25 \%$ get multiple scars and $64 \%$ end up with single vertical splotch strip [50]. When tree skin becomes wet it can cause flashover along the trunk due to relatively lower resistance. Lightning is responsible for the majority of jungle fires. Positive lightning causes more damage to trees than negative lightning due to its high action integral ( $\int I^{2} d t$ ) over the return stroke. Multiplestroke lightning flashes are more dangerous due to their continuing currents, lasting for 400 to $600 \mathrm{~ms}$, capable of causing tree ignition [51]. Lightning damage rate increases with depending on type of soil. Clay, cultivated soil and sand resistivities are 25 to 70,50 to 250 and 1000 to $3000 \Omega \mathrm{m}$ [52]. Trees in loam or sandy soils are more likely to attract lightning than clay, marl and calcareous soils.

Lightning frequencies vary from $\mathrm{DC}$ to $120 \mathrm{MHz}$ radio waves in addition to UV, UV and IR brilliance. UV can cause photokeratitis and erythema, visible light causes skin and retinal burns causing color vision or night vision problems. IR heat causes cataracts, corneal and skin burns like lasers. Lightning brilliance is not less than lasers lights therefore the injuries may be similar in nature. Lightning power varies from a few TW to $400 \mathrm{TW}$ in $70 \mu \mathrm{s}$ to $500 \mathrm{~ms}$ durations. Variation of power and exposure duration of small cute $\mathrm{He}-\mathrm{Ne}$ lasers for minimum retinal damage [53] and 
corresponding lightning powers in similar exposure times are shown in Fig. (5).

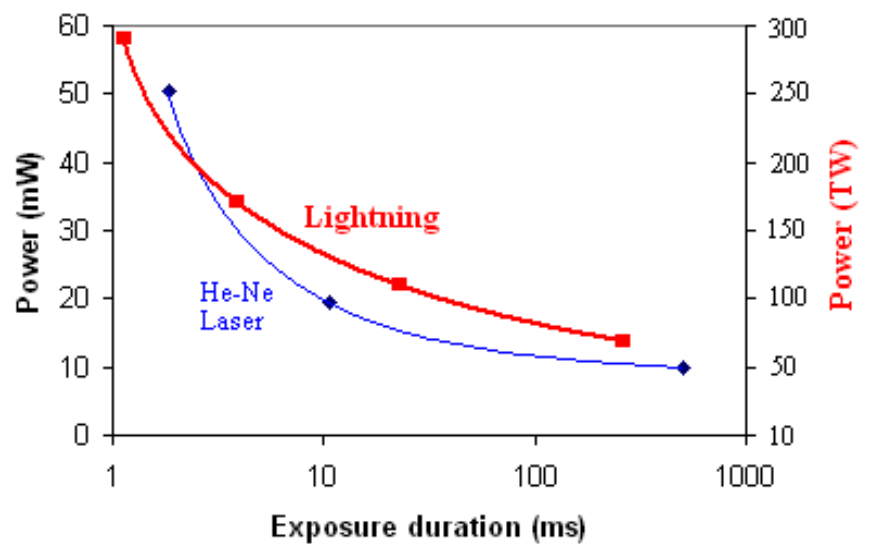

Fig. (5). Lightning power compared to laser safety limits.

Generally it is accepted that AC shock is more dangerous than DC and lightning. Three times higher DC voltage inflicts same injuries to victim as equivalent $\mathrm{rms}$ AC. Generally DC voltage is taken equivalent to rms AC which equals to peak $\mathrm{AC}$ divided by square root two. Lightning voltage is higher but body resistance and air breakdown limit voltage across human head and feet to $4 \mathrm{kV}$ allowing $4 \mathrm{~A}$ current for less than one microsecond reducing the action integral $\mathrm{A}^{2} \mathrm{~s}$ below the danger threshold of 10-50 J for negative and above the lower limit of critical threshold for positive lightning strikes. Negative lightning may have multiple strokes in it whereas positive lightning has only few strokes.

\subsection{Lightning-Airplane Interactions}

Pilots occasionally report lights flickering and momentary interference due to lightning. They also ensure static charge dissipaters are in order before take-off but try as far as possible to keep away from the cumulonimbus clouds. Aircraft skins consist of conductive aluminum which conducts electricity [54]. Composite materials also have embedded layer of fibers designed to carry lightning currents. Radar is located in nose composite material radome fitted with lightning diverting metallic strips. Lightning starts at aircraft extremities like radome, fuselage, nacelle, empennage or wing tip. Lightning starts from nose cone or wing tips and extends off the aircraft to nearby clouds. Over $96 \%$ lightning strikes to aircrafts occur when it is within or $3 \%$ when it is below the clouds. Hardly $<1 \%$ lightning occur when aircraft is on side or above the clouds. If lightning enters at nose cone then final entry of subsequent stroke may be in middle of fuselage, depending upon the speed in air, and similarly the initial exit of lightning corresponding to first stroke is in second half of fuselage whereas final exit near the tail. If lightning attaches itself to the rear of aircraft, strokes entries and exists reverse from tail to nose or wing to wing sides [55]. Generally every aircraft receives at least one lightning incidence per 2,500 flight hours that is roughly 1/plane/year but some aircrafts like S-61N, Norway, meet 13 strikes in 8 years. Aircraft suffers lightning for being at wrong place at wrong time. Aircraft lightning may cause dielectric breakdown, blasting, melting, bending, burning, pitting, magnetic pinching, shockwave, overpressure, flash blindness and damage to internal wiring. Associated effects may include aperture coupling due to magnetic under rapid rise of current and increase in voltage drops in structures. After lightning strike incidence chances of pitting, burn marks and circular holes on body are likely to be observed.

Lightning often enters from wing tips and exits below nose cone or tail underneath. To inspect lightning damages, the aircraft is divided into three zones. Zone 1 covers radome, nacelles, wing tips, horizontal stabilizer tips, elevators, vertical fin tips, ends of leading edge flaps, trail edge flap track fairings, landing gear, water waste masts, air sensors, angle of attack vane and temperature probe. Zone 2 consists of lightning entry, exit and side flashes. Zone 3 consists of examination even if no damage occurred. Inspections of zone 3 also include examination of broken external lights, cracked lenses and visible damage marks. Landing gear door, magnetic compass, fuel gauges and static discharger wicks. Lightning entry and exit points and nearby areas are thoroughly inspected [56]. Protruding points on ground concentrate potential gradient but flashover soon due to air dielectric breakdown at $30 \mathrm{kV} / \mathrm{cm}$ like corona discharge (St. Elmo's fire). During the lightning process leader develops $500-900 \mathrm{kV} / \mathrm{m}$ and streamers $5.5 \mathrm{kV} / \mathrm{m}$ gradients. Lightning time to peak in air is $1.5 \mu \mathrm{s}$ with $40 \mu \mathrm{s}$ duration. Duration between return and second stroke is 10 $\mathrm{ms}$ but $60 \mathrm{~ms}$ between subsequent strokes. Continuing current for over $100 \mathrm{kA}$ peak is $400 \mathrm{~A}$ after the fifth stroke and $200 \mathrm{~A}$ after tenth stroke. Negative cloud lightning flash has maximum $140 \mathrm{kA}$ peak current, $0.7 \times 10^{6} \mathrm{~A}^{2} \mathrm{~s}$ action integral, $22 \mathrm{C}$ impulsive and $200 \mathrm{C}$ total charge, whereas, positive cloud lightning flash can have maximum $200 \mathrm{kA}$ peak current, $11 \times 10^{6} \mathrm{~A}^{2} \mathrm{~s}$ action integral, $120 \mathrm{C}$ impulsive and $350 \mathrm{C}$ total charge. Lightning activity is more prevalent at 5,000 to 15,000 feet peaking at altitude of 10,000 feet as shown in Fig. (6).

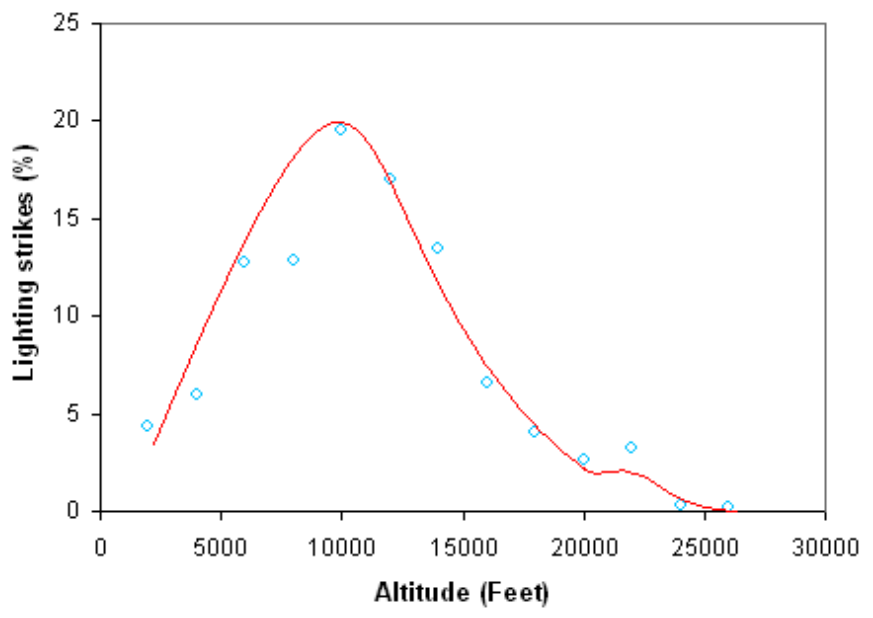

Fig. (6). Lightning activity variation with altitude [57-59].

Lightning protection on airplanes includes wire bundle shields, ground straps, composite structure expanded foils, wire mesh, aluminum spray coating, embedded metallic wires, metallic picture frames, diverter strips, metallic foil liners, coated glass fabric and bonded aluminum foil. Outside aircraft body metal tracks conduct and static dischargers dissipate lightning at aircraft extremities like side wings, radome and fuselage underneath. Modern aircraft companies conduct lightning test in lab before launching aircraft for commercial flights. Trained pilots inspect static 
dischargers before take off. FAA certification requires to include basic airframe lightning protection (29.610), fuel system lightning protection (29.954), equipment, systems, and installation functionality during lightning (29.1309). Federal Aviation Authority (FAA) aircraft's lightning protection standard supplies comprehensive guidelines [57]. FAA advisory (AC 20-136) requires protection of flight critical and essential electrical and electronic systems against indirect lightning effects. It requires lightning and static electricity protection (29.610), failure of any component should not compromise continuity of flight to destination (29.1309) [58]. Lightning strikes on aircrafts require thorough inspection and repair which affects airline operations, and causes costly delays and service interruptions.

Airborne things such as birds and vehicles may become part of lightning channels. Birds are likely to be electrocuted but aircrafts have special metallic structure to dissipate and divert lightning currents by 5 top $200 \mathrm{M} \Omega$ static charge wick devices. Lightning causes DC to $1000 \mathrm{MHz}$ noise but communication equipment are not affected due to metallic aircraft shielding and discharge devices at aircraft extremities. Drones fly at higher altitude above clouds during surveillance but may fall victim to lightning when come down to fire missiles on targets. A few drones were reported smashed without giving cause of damage in bad weathers. Cloud to-ground lightning occurs from 5 to $15 \mathrm{~km}$ altitudes but highest frequency of lightning strikes is from 10 $\mathrm{km}$ high clouds which correspond to aircraft heights. Aircraft is above clouds during flight therefore chances of lightning strikes are higher during take-off or landing when aircraft is going up or down. A piston-type aircraft is likely to encounter 1 lightning strike per 2,475 hours flight while Turboprop and jet-type aircrafts are likely to encounter 1 per 3,807 and 10,414 hours flights. Average chance of 1 lightning strike for an aircraft is per 2,967 flight hours [59].

Lightning incidences depend on aircraft exterior lightning dissipation mechanisms not engine types. Important lightning-related air accidents include Herne Bay at Kent [60] and Boja Air Flight 213 [61] accident near Islamabad on 20 April 2012 killing all 121 passengers on board, LANSA flight 508 in 1971 killing 91 on board in Amazon rainforest, Apollo 12 Mission's Saturn V rocket over 36 seconds after lift off in 1969 for being part of lightning channel and Pan Am Flight 214 in Maryland by severe electrical storm in 1963 killing 81 passengers on board [62]. Several aircraft lightning incidences have been noted in last decade but no injury reported due to enhance lightning charge dissipation conductors over aircraft body. Aircraft accidents and incidents continue due to mechanical failures, birdage, cyclones, visibility and lightning strikes. Wikipedia reports 40 accidents and incidents in 2009, 39 in 2010, 36 in 2011, 27 in 2012 and 12 in 2013 (Jan-June). Modern aircrafts hardly fall or victim of lightning due to advance lightning protective measures but any aircraft under swirling clouds may lose balance and become fall prey to lightning strike. Eye witness explained the Bojha Air Flight 213 on 20 April 2012 dived down and lightning occurred from cloud to aircraft via tail down to earth which caused flash in air. Weather data show existence of anvil type cloud on site at time of accident after sunset.

\subsection{Lightning-Wind Turbine Interactions}

Wind turbines use two current sensors, first on generator path to ground, and second around tower ground strap. Current sensors can measure maximum 5 to10 kA@7 $\mu$ s with rise/fall time of $1 \mu \mathrm{s} / 10 \mu \mathrm{s}$. Turbine lightning strike is normally detected by above current sensors (9 V DC) whose output is converted to light pulses and sent down to data acquisition box (Campbell Scientific make, CR 500 data logger, $12 \mathrm{~V} \mathrm{DC}$ ) attached to base webbing. Current sensor is likely to produce high voltage (Ldi/dt) due to high rate of rise. Lightning currents measurement experiments with Rogowski coil and B-dot sensors shows upper frequency cut off at $20 \mathrm{MHz}$ with $50 \Omega$ matching terminations. A $10 \mathrm{~m}$ long PEM CWT $600 \times / 11700$ type Rogowski coil can measure up to $1 \mathrm{MHz}$ with peak di/dt of $150 \mathrm{kA} / \mu \mathrm{s}$ [63]. A comparative study of Hall, magnetic and optical current sensors proved superior performance of fiber optic current transducers [64]. Electrical storm identification device (Global Atmospherics make) is often installed on the roof top of near by building. ESID detect oncoming thunderclouds over $48 \mathrm{~km}$ distance and communicates to receiver unit via fiber optic cable. A PC based storm tracker (Boltek make) software/hardware helps track $483 \mathrm{~km}$ far thunderclouds. CCD cameras can supply video signals of wind turbine during storm or zoom to monitor remote clouds. Wind turbine interfaces with utility at 11 or $25 \mathrm{kV}$ distribution line.

Utility feeder may inject transients to wind turbine or vice versa, which requires to install PQ surge monitor. In case of wind farms each wind turbine has to be equipped with software and hardware. Lightning frequency to various units in a wind park was found to vary from 5 to 12 per year causing 429 (36 Hrs per turbine) to $2800 \mathrm{Hrs}$ (233 Hrs per turbine) downtime [65]. Lightning related faults include damage to resistor networks protecting SCADA, power supplies, transducers, control boards, SCADA communication card, SCADA modem, wind vane, rotor driver board, gear box sensor, blade, and converter, inverter, overcharge dissipation lights in case of small personal wind turbines. Large wind turbines lightning caused damages cost $\$ 427$ to $\$ 2577$ per turbine per year. Frequency inverters and the thyristor are protected against partial lightning currents and transient over voltages by class I spark gaps at the voltage level of $690 \mathrm{~V}$, which is typical for wind turbines. Generator is protected by class II arresters at rotor, stator and blade. Metering equipment is protected by surge protective devices. Control equipment, aviation lights, power supply, and weather sensors must be protected. A modern wind turbine requires at least 13 surge protective devices [66].

The third industrial revolution has accelerated the deployment of wind turbines under renewable energy visions 2020 (Asia), 2030 (USA) and 2050 (EU). IEEE standard 487-2000 supplies guidelines on practice for the protection of wire-line communication facilities, serving electric power stations but it gives little information on wind turbine protection due to lack of guidelines. Researchers suggest development of new lightning protection standards for wind turbines [67]. Lightning affects not only mechanical hardware, like blades and nacelle [68], but also turbine control system [69]. Wind turbine power capable is dropped 
down within metallic tubular pole ( $2 \mathrm{kVA})$ yet lightning may come through other control cables which may be replaced by fiber optic links. Wind turbines are not only victims of direct strikes but also indirect side flashes from near turbines or trees [70]. Lightning protection under existing guidelines such as NFPA-780 (installation of lightning protection systems), IEC-61024 (protection of structures against lightning), 61662 (lightning risks) or 61312 (protection against lightning impulses), IEEE 142-1991 (grounding of industrial and commercial power systems) and NASA-CR168229 (how to protect wind turbine) are good but not adequate that is why wind turbines continue to fail. Many researchers in famous institutions have proposed lightning protection schemes for composite rotor blades [71], general lightning protection of wind turbines [72], and lightning protection of wind turbines [73].

IEC 16400-24 supplies more specific information on lightning protection of wind turbine generator systems. More specific information on lightning may be obtained from standard text books $[1,18]$. Federation of Finnish Financial Services (FF) recommends installing wind turbine protective devices in accordance with IEC 61400 to protect damage protection. Inspection intervals on lightning protection may not be longer than two years. Lightning protection must be examined from the blade's receptor to the grounding electrode so that any bad connections or partially broken cables are noticed. Electrical installations must be thermographed by a competent thermographer during testing phase when the turbine is running, and later according to the maintenance plan, or at least once every two years. Any dangers must be eliminated and faults repaired, and the thermography must be documented [74]. Due to oil and gas depletion scenarios the power companies worldwide are trying to harvest wind potentials. Global installed wind power capacity was $239 \mathrm{GW}$ by end of 2011 .

To harvest more power high rating large wind turbines are under consideration. By 2012 wind turbine blade sizes have grown to $150 \mathrm{~m}$ in diameter which is nearly the twice of largest aircraft size. Widespread roll-out of wind turbines in different countries, being risk to migratory birds, has increased new targets for lightning. World wide annually $36 \%$ wind turbines fall victim to lightning strikes [69]. Hybrid systems consisting of wind turbines, solar cells and biogases need special protection standards due to their open locations [75]. Prior experience and standards deal with grounding of slow AC/DC systems which do not suffice for lightning attacks on wind farms [76]. The cause of wind turbine damages by lightning was recently observed by the high voltage Marks impulse generator experiments in Japan [77]. It was noted long blades of composite materials without embedded conductors easily burn in lightning strikes. However, it was noted the polluted blades attract less lightning than non-polluted blades.

IEC $61400-24$ is considered the most comprehensive standard mentioning laboratory scale tests to verify wind turbine outdoor lightning endurance. It describes blade lightning attachment and high current bearing tests at 90,60 and $30^{\circ}$ orientations. IEC $62305-1$ describes air or conductor termination of lightning. A $10 / 350 \mu$ s test pulse is injected with peak $200 \mathrm{kA}$ current and specific energy of $10 \mathrm{MJ} / \Omega$. Open arc may carry 300C charge and associated magnetic effects. Impulse test is also carried on bolted structures as shown in Table 2 [78].

Table 2. 20 Year Life Test Using $10 / 350 \mu$ a Impulse

\begin{tabular}{|c|c|c|c|}
\hline \multicolumn{2}{|c|}{ Bolted Connection } & \multicolumn{2}{c|}{ Arc Attachment } \\
\hline Numbers & Current (kA) & Number & Charge (C) \\
\hline \hline 2 & 200 & 4 & 300 \\
3 & 150 & 4 & 200 \\
8 & 100 & 6 & 150 \\
7 & 50 & 6 & 100 \\
\hline
\end{tabular}

IEC 61400-24 allows performing physical test or carrying out simulation to verify that normal lightning incidence might not affect wind turbine performance. Nacelle, hub, down conductors and sensors must continue their normal routine work during lightning. Experimental and numerical techniques for wind turbine testing are described in detail elsewhere [79]. Researchers usually focus direct hit of lightning on wind turbines but field experience and simulation studies show $50 \%$ of lightning arrester failures occur due to back flow of lightning from distribution system [80].

\subsection{Lightning-LRT Interactions}

Light Rail Transits (LRT) may consist of 600-800 V DC. Rail motor is connected to negative wire on ground and positive wire in air through overhead contactor system. AC system from electric grid feeder to power rectifier transformer is protected by normal AC lightning arrester. However, DC system from rectifier to switchgear, cable and overhead contactor is protected by DC lightning arresters. Lightning arrestors calculations are often done for $\mathrm{AC}$ and then decreased for DC circuits. Dev Paul has done the basic lightning protection work for LRT. He suggests to employ $900 \mathrm{~V}$ lightning arrester for $800 \mathrm{~V}$ LRT [39]. LRT after electric grid, telecom towers and wind turbines is the big victim of lightning. Aircrafts are well equipped and human bodies can withstand 10 to $50 \mathrm{~J}$ energy thunder bolts depending upon individual's health, but delicate electronic components are easily damaged with just few $n J$ to $\mu J$ lightning energies. LRT insulator critical flashover voltage may be given by

$\mathrm{V}_{\mathrm{CFO}}=171+489 \times \mathrm{L}_{\mathrm{INS}}$

where $\mathrm{L}_{\mathrm{INS}}$ is length of insulator [81]. IEEE Standard 80, supplies guidelines for grounding of LRT DC system. NFPA 130 is the primary standard for fixed guide way transit and passenger rail systems. AREMA discusses rail transit in chapter 4. Human touch with LRT live wire makes a parallel circuit LRT ground, human body plus parallel resistances of feet to ground. Flow of 60 to $80 \mathrm{~mA}$ current through body at touch voltages of 69 and 92 volts may prove fatal. Dalziel recommends the following equation for non fibrillation $\mathrm{AC}$ current of a $50 \mathrm{~kg}$ human body [82].

$\mathrm{I}_{\mathrm{N}-\mathrm{Fib}}=116 / \sqrt{t}$

IEEE Std 2000 recommends the following equation for non fibrillation $\mathrm{AC}$ current of a $70 \mathrm{~kg}$ human body 


$$
\mathrm{I}_{\mathrm{N}-\mathrm{Fib}}=157 / \sqrt{t}
$$

Equation for non fibrillation DC current (three times higher) is given by

$\mathrm{I}_{\mathrm{N}-\mathrm{Fib}}=348 / \sqrt{t}=348 / \sqrt{0.08}=1.2 \mathrm{~A}$

In case of LRT maximum time may be $5 \mathrm{~s}$ for accelerating train and $0.08 \mathrm{~s}$ for feeder breaker trip in case of short circuit. Maximum tolerable step and touch potentials for 50 and $70 \mathrm{~kg}$ bodies are given by

$$
\begin{aligned}
& V_{50 \mathrm{~kg}}=\left(157+0.236 \times C_{S} \times \rho_{S} / \sqrt{t}\right. \\
& V_{70 \mathrm{~kg}}=\left(157+0.236 \times C_{S} \times \rho_{S} / \sqrt{t}\right.
\end{aligned}
$$

where $C_{S}$ is surface layer derating factor. IEEE Std 802000 defines tolerable touch voltages to be

$V_{\text {mesh }}=\left(K_{m} \times K_{i} \times \rho \times I / L\right.$

$V_{\text {step }}=\left(K_{S} \times K_{i} \times \rho \times I / L\right.$

where $\mathrm{L}$ is length of ground conductor, I ground fault current, $K_{m}$ mesh coefficient, $K_{s}$ step coefficient, $K_{i}$ irregularity factor. Stray currents and potential may be minimized by increasing track to earth resistance [83]. Normally LRT systems trip if track voltage exceeds 60 to 90 $\mathrm{V}$ DC. If ground fault occurs on OCS then ground potential may rise to $750 \mathrm{~V}$ DC. LRT overhead contactor system (OCS) completing electric circuit is primary victim of lightning strikes. Frequency of lightning flashes $\mathrm{N}_{\mathrm{OCS}}$ on electric rail OCS may by given by [5].

$\mathrm{N}_{\mathrm{OCS}}=\mathrm{L} \times \mathrm{B} \times \mathrm{N}_{\mathrm{g}}$

where $\mathrm{L}, \mathrm{B}$ and $\mathrm{N}_{\mathrm{g}}$ are length, width (in $\mathrm{km}$ ) and number of cloud to ground lightning flashes are given by [84]

$\mathrm{N}_{\mathrm{g}}=0.04 T_{d}^{1.25}$ flashes $/ \mathrm{km}^{2} / \mathrm{yr}$

where parameter $T_{d}$ varies from 40 to 60 giving average value of $\mathrm{N}_{\mathrm{g}}$ to be 6 to 7 . Rate of change of current (di/dt) and voltages $(\mathrm{dV} / \mathrm{dt})$ assuming surge impedance of $40 \Omega$ are $5 \mathrm{kA} / \mu \mathrm{s}\left(5 \times 10^{9} \mathrm{~A} / \mathrm{sec}\right)$ and $200 \mathrm{kV} / \mu \mathrm{s}\left(2 \times 10^{11} \mathrm{~V} / \mathrm{sec}\right)$ on parallel LRT contactor and cable system [85]. The lightning surge energy for initial $0.18 \mu \mathrm{s}$ flashover period may be calculated by following expression

$$
\begin{aligned}
W= & \int_{0}^{t} V I d t=\int_{o}^{t} \frac{d v}{d t} \frac{d i}{d t} t^{2} d t=2 \times 10^{21} \times 5 \times \\
& 109\left[t^{3} / 3\right]_{0}^{18 \times 10^{-4}}=1.94 k J
\end{aligned}
$$

If OCS has no DC surge arrester then damage threshold voltage is $35 \mathrm{kV}$. Energy discharged by surge arrester for line length $\mathrm{L}(\mathrm{km})$, arrester discharge voltage $\mathrm{E}_{\mathrm{A}}(\mathrm{kV})$, switch impulse current $\mathrm{I}_{\mathrm{A}}(\mathrm{kA})$ and lightning speed $\mathrm{v}(\mathrm{km} / \mathrm{s})$ may be estimated by

$\mathrm{W}=2 \mathrm{~L} \times \mathrm{E}_{\mathrm{A}} \times \mathrm{I}_{\mathrm{A}} / \mathrm{V}$

If surge wave shape is known then we may use following expression [39]

$\mathrm{W}=\mathrm{K} \times \mathrm{V}_{\mathrm{C}} \times \mathrm{I} \times \Delta \mathrm{t}$

where $\mathrm{K}$ is constant for triangular (0.5), rectangular (1) and exponential (1.4) waves, V clamping voltage, I impulse current and $\Delta \mathrm{t}$ impulse duration. For OCS/cable surge impedance of $40 \Omega$, surge voltage twice of dry flashover (35 $\mathrm{kV}$ ) and arrester discharge voltage of $7 \mathrm{kV}$ the arrester discharge current may be given by

$I_{A}=\left(2 V_{\text {thresh }}-V_{\text {dis }}\right) / Z_{\mathrm{s}}=(2 \times 35-7) / 40=1.575 \mathrm{kA}$

The energy associated with lightning surge current may be calculated by

$\mathrm{W}_{\mathrm{A}}=2(3 / 4)(1 / 190) \times \mathrm{V}_{\text {dis }} \times \mathrm{I}_{\mathrm{A}}=88 \mathrm{~J}$

Time to travel $3 / 4$ mile is $3 / 4 \times 1 / 90=4 \mu$ s. For strokes it is $8 \mu \mathrm{s}$ and longer for multiple strokes. It is reasonable to use $300 \mu \mathrm{s}$ that increases discharge energy accordingly. A few strokes lightning strikes limit to 2 to $3.5 \mathrm{~kJ}$ that is below 4.4 kJ limit (@2.2 kJ/kV) for 2kV DC surge arrester. Lightning arrester must be chosen to withstand all types of lightning strikes from negative to positive and one to multiple stroke strikes. Transient simulation analysis (EMPT) can help reduce downtime [86]. IEEE has recently launched draft of new standard IEEE P1653.1, 2011 for LRT DC traction [87].

\subsection{Lightning Interactions with Energy Lifelines}

Lightning interacts with energy lifelines to cause disruptions in oil, gas and power supplies. Energy lifelines like oil tankers [88], buried gas pipelines [89], underground petroleum pipelines [90], high voltage underground cables [91], overhead power lines [92], power transformers [93], wind turbines [77], surge arresters [94], and telecom lines [95] are vulnerable to lightning attacks. Induced voltages on overhead lines [96] and underground pipes or cables [97] due to nearby lightning were investigated well in mid 1990s. Rubinstein developed formulae for calculation of induced voltages at close, intermediate and long range [98]. Analytical models were developed to estimate induced voltages on power lines for vertical, horizontal and inclined lightning at various orientations and ranges.

Oil, gas and water can be transported through pipe at lowest energy per unit cost. Apart from floods and earthquakes, the pipelines are affected by corrosion from bottom and lightning from top. Cathodic protection of pipeline is may be done by sacrificial anodes and impressed currents. Cathodic protection is a method of corrosion control applied to underground pipelines and metallic structures. It is used in conjunction with coatings on pipes. Principle of cathodic protection is to prevent anodic sites on structures by allowing anodic reactions to occur.

$2 \mathrm{Fe}+2 \mathrm{H}_{2} \mathrm{O}+\mathrm{O}_{2} \rightarrow 2 \mathrm{Fe}(\mathrm{OH})_{2}$ (Rust)

Galvanic and impressed currents may be used to protect pipes. Galvanic protection does not use any external power. It uses fixed electronegative potentials with little galvanic currents. Impressed current method uses external variable potential high current sources. Positive pole is connected to the ground (sacrificial) anode and negative to oil or gas pipeline to be protected from rust.

Lightning activity in air induces voltages on pipelines. $50 \%$ lightning energy is wasted in contact objects, and the rest goes to earth by passing through pipelines. Lightning current varies from 10 to $100 \mathrm{kA}$, which on basis of $50 \%$ hypothesis may impress 5 to $50 \mathrm{kA}$ currents on buried cables and pipelines. When lighting strikes on trees, the voltage 
induced on pipe near it through soil conductivity may be given by

$$
V_{\text {pipe }}=L_{\text {Pipe }} \frac{d i}{d t}
$$

For pipe inductance of $0.5 \times 10^{-6} \mathrm{H} / \mathrm{m}$ and rate of current rise of 8 to $10 \mathrm{kA} / \mu \mathrm{s}$ the induced voltage on pipe may rise to 4 to $5 \mathrm{kV}$, which can damage the rectifier. Protection simulation limits the induced voltage to $1.5 \mathrm{kV}$ [90], which is in accordance with BS60950. Coating and current injection techniques are used to control corrosion of underground oil and gas pipelines. Field measurements show the soil resistance is $1 \mathrm{k} \Omega / \mathrm{m}$ and capacitance $221.35 \mathrm{pF} / \mathrm{m}$. Pipe coating material resistance is about $10^{10} \Omega / \mathrm{m}$ and capacitance of $10.42 \mathrm{pF} / \mathrm{cm}^{2}$. Pipes are coated to avoid direct contact with soil that forms RC networks in soil and on coatings as shown in Fig. (7).

Pipelines are the cheapest method to transport liquid fuels and gases. Natural location of fossil fuels in Peninsula Arabia and Russia permit gas pipelines to Europe but do not allow installation of oil pipelines to China and America at the moment due to high mountains and Atlantic Ocean. Ships and oil tankers are the most attractive alternative options where pipelines can not be laid for terrain and security reasons. Lightning frequency is higher on land compared to sea. Oil tankers use floating roof plates to suppress crude evaporation during transport [88]. Mobile oil tankers are potential targets for lightning strikes. Oil tanker volume is usually $100,000 \mathrm{~m}^{3}$ which if hit by lighting can loose a lot of oil creating environ catastrophe. Oil tanker wall is usually $23 \mathrm{~m}$ high which is $3 \mathrm{~m}$ taller than highest floating roof plate position. Sealed floating roof is connected to tanker wall shell by shunt slide contactors in addition to a cable connected to the top of shell. Lightning strikes to body wall are less dangerous compared to central floating roof but both are equally exposed to lightning. Rolling sphere method recommends to protection on $18^{\circ}$ intervals along the circumference. It requires 20 protection rods which may reduce to 14 if one increases size from 3 to $18 \mathrm{~cm}$. Experience suggests the scalable grounding devices for floating roof oil tankers.

\section{LIGHTNING PROTECTION AND CONTROL}

Lightning is cause of failures and damages to utility equipment. IEEE guidelines for surge protection of equipment connected to $\mathrm{AC}$ power system and communicat- ion circuits provides safeguard against lightning transients. In tropical regions only $10-20 \%$ of the lightning flashes strike the ground, rest $80-90 \%$ occur within clouds [99]. Power system insulation coordination is designed to withstand lightning surges still damage occurs during direct strikes. It is advisable to install surge protection devices (SPD) on building entrance. Installations must be grounded using joule criterion ratings. Utilities deploy arcing horns and metal oxide varistors on high voltage lines, transformers and bus bars. Building must have lightning rods on rooftop. Satellite dish coax cable must be bonded to building ground with at least \#10 wires (NEC Art.810.21). Power line may pass through protector in home to absorb lightning surges. It is advisable to divide and control lightning strike energy using multiple grounds. Use lightning divider for lightning energy traveling down the tower. Improper grounding causes damage to equipment from near by objects through potential difference and no special protection by ground potential rise (GPR). Gas tubes are chosen for telecom terminations to shunt incoming energy but no protection available against GPR or outgoing energy. IEC and IEEE standards offer essential protection schemes for equipment and personnel.

Use of optical isolators in the communication circuits may help minimize remote lightning hazards. Optical fibers have already been integrated in DC substation SCR trigger control, OPGW, communication and control of wind turbines in high isokeraunic level places. Lightning control to protect key locations and human life seems more probable than harnessing lightning to power homes and industries. Laser beams may help harmlessly divert the lightning surges to protect humans, aircrafts, wind turbines, LRT, electric grid and telecom towers. Most researchers concentrate on thermal effects but laser air photo-selective interactions seem more interesting. Rocket-triggered lightning discharge (RTLD) was successfully conducted in 1967 [100]. Similarly, RTLD experiments were reported in France [101102], USA [103], Indonesia [104] and China [105]. Japanese have spent a long time on laser-triggered lightning [106]. Florida rocket-triggered lightning experiments found 202 of 299 RTLF (67\%) for negative overhead space charge and 6 of $20(30 \%)$ RTLD for positive lightning succeeded. Chinese RTLD experiments in Gansu (China) [107] reported 10 of 35 (29\%) for positive overhead charges. Multiple experiments show it requires more energy to conduct RTLD of the positive compared to negative overhead charges. Cloud charge electric and magnetic fields may be estimated for

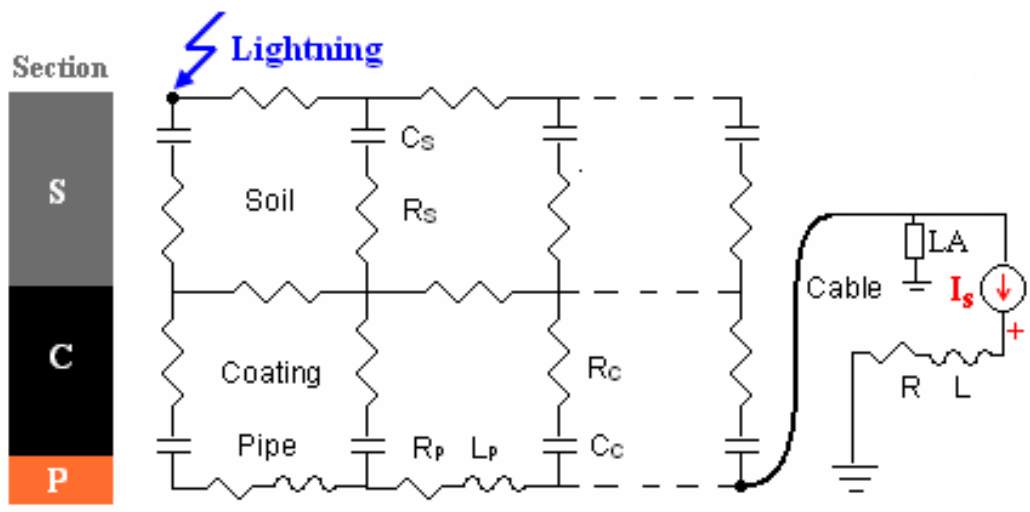

Fig. (7). Equivalent pipe cathodic protection circuit under lightning strike. 
rocket-triggered lightning discharge experiments, which are given by [18, 108-109],

$$
\begin{aligned}
& d E(t)=d Q(t) H(t)\left[H^{2}(t)+D_{E}^{2}\right]^{-1.5} / 2 \pi \varepsilon \\
& B(t)=\mu \times I(t) H(t)\left[H^{2}(t)+D_{B}^{2}\right]^{-0.5} / 2 \pi D_{B}
\end{aligned}
$$

where $\mathrm{dE}(\mathrm{t})$ is change in electric field at distance $\mathrm{D}_{\varepsilon}, \mathrm{dQ}(\mathrm{t})$ is charge on cloud tip, $\mathrm{H}(\mathrm{t})$ height of leader tip at any moment, $D_{B}$ is distance of magnetic flux density from base of triggered lightning, and $\varepsilon$ and $\mu$ are air permittivity and permeability respectively.

Several rocket-triggered lightning discharge (RTLD) experiments were reported from 1970s to 1990s, and laser guided lightning discharge (LGLD) [110] and microwavetriggered lightning discharge (MTLD) [111] experiments were proposed and many earlier attempts reviewed [112]. RTLD technology is almost matured but the LGLD failed to replace RTLD in outdoor experiments. Leading LGLD researchers could not show outdoor experiments $[113,110]$. Experts point out the LGLD causes bi-directional uncharged or net zero potential leaders in atmosphere. The potential difference between leader and cloud initiates lightning in 10$20 \mathrm{~ms}$ but the laser filamentation is a short-lived phenomenon. Natural light produces white light that can be reproduced using lasers [114]. The leader channel ceases to propagate when the difference between the leader potential and cloud is below the threshold necessary to carry on breakdown. Several attempts were made in USA and Japan to conduct laser-triggered guided lightning discharge (LTGLD). New Mexico researchers demonstrated laser triggered guided lightning discharge in laboratory and are working on long range propagation barrier facing long duration problem, cloud charge distribution over clouds in horizontal patches [18], or as a vertical line [115]. Recent reports show the kilometer long range remains no more a problem [116]. Japanese used pulsed $10.6 \mu \mathrm{m} \mathrm{CO}_{2}$ laser in their model experiment [113] but Americans used pulsed 248 $\mathrm{nm} \mathrm{KrF}$ femtosecond laser to trigger the discharge and 530 $\mathrm{nm} \mathrm{CW}$ laser to maintain the conductive path [110]. Ophir Corporation proposed using a tunable dye laser with $308-\mathrm{nm}$ $\mathrm{XeCl}$ to produce $314.5 \mathrm{~nm}$ laser pulses to excite argon in the air. Several others think use of distributed feedback dye laser can provide multiple lines together to excite wide range of molecules [117].

"Mysyrowicz points out that harnessing lightning could have many practical applications - both for studying the elusive phenomenon and for draining electrically volatile storms before they can wreak unpredictable havoc. Lightning control, if you want to protect particular sites, would be very useful. You could avoid lightning on very expensive or fragile sites," explains Mysyrowicz. For example, in 1987 a US\$78 million Atlas Centaur rocket carrying a \$83 million military communications satellite had to be destroyed after it went off course after launch. Investigators said the malfunction may have been caused by lightning. University of New Mexico Professor, Jean-Claude Diels, agrees the technique has the potential to call down lightning strikes. But he says the ionization caused by the laser pulses must last more than a thousand times longer than the nanosecond it does now. Professor Diels adds that he thinks it possible that the plasma filaments created so far may not have converted into electrical discharge inside the targeted clouds. There is some electromagnetic radiation generated by the filaments themselves, which may have contributed to the detected signal" [118]. Peak lightning stroke duration varies from 1 to $2 \mu$ s so the laser induced ionization must stay at least for a few $\mu \mathrm{s}$, although, longer would be still even better. A model based on Diels work suggests that UV (220-420 nm) $200 \mathrm{ps}$ laser pulses with a peak power of around $50 \mathrm{MW}$ (or $12.5 \mathrm{~mJ}$ input energy) and a beam size of $100 \mu \mathrm{m}$ are the optimal tool to trigger outdoor lightning. Actual lightning channel is very thin but size of luminous line appears 2-6 $\mathrm{cm}$. A discussion on $\mathrm{CW}$ and repetitively pulsed lasers was initiated in energy context elsewhere [119], and considerations may be tested for triggering and guiding lightning discharge [120]. Many researchers think Professor Diels's approach holds the key to elixir. The missing link may lie in nonlinear atmospheric optics [121]. If the duration of repetitively pulsed laser is shorter than the ionization decay time, then it can maintain it. Ability of ultrafast laser filaments to trigger and to guide large scale discharges has been the subject of many studies for several years [122-124]. A recent experimental result has shown for the first time that the filaments are able not only to trigger and guide but also to divert an electric discharge from its normal path [125]. Many researchers believe lasertriggered guided discharge of clouds using low power suitable pulse repletion and wavelength is possible [126127]. Features of laser triggered lightning were reported a few years ago [128].

Professor Martin Uman opines it is not possible to capture 50 to 100 lightning flashes every second worldwide. However, he notes that if somehow the whole of lightning energy is harnessed then one flash can power a lamp for few months. Most energy in lightning is converted to flash (light), thunder (sound), heat (filament) and radio waves before it reaches earth. Many researchers think if we can download the charges by providing safe passage through lasers or wires, then it can be harnessed in a controllable fashion. A continuous power (energy) associated with worldwide lightning events varies from 1,000 to 320,000 MW $(89,000 \mathrm{kWh})$. Several attempts have been made to harness lightning but it seems hard to collect the scattered atmospheric electric energy around the globe. A moderate thunderstorm may generate several hundred megawatts of electrical power [29]. According to the Discovery Channel Report one lightning strike has enough energy to light $150 \times 10^{6}$ light bulbs [30]. Much information is available, such as, polarization, electrostatic induction, supercooling, cosmic rays and yet the lightning phenomenon has still to be debated [128]. A cloud-to-ground lightning flash involves energy of $1.3 \times 10^{9} \mathrm{~J}$ [31] using few joules energy [126] but it is impossible to utilize it. If lightning energy somehow is captured then it might allow to operate five $100 \mathrm{~W}$ incandescent lamps continuously for one month probably $\left(5 \times 100 \mathrm{~W} \times 3600 \mathrm{~s} \times 24 \times 30=1.3 \times 10^{9} \mathrm{~J}\right)$ which equals monthly energy consumption of an average household. Oil and gas depletion scenarios drive scientists and engineers to look at alternative ways to capture and store lightning [129]. Laboratory-scale simulation experiments continue with intention to capture lightning energy [130].

One would need to attract 12 flashes to an energy storage facility in order to operate these five light bulbs for one year. Due to less chance of lightning striking the same location, 
the number of lightning capturing towers would need to operate only five $100 \mathrm{~W}$ bulbs, but in areas of moderate lightning activity this would be 48 to 72 . Thus the main problems with using lightning energy include the power associated with a lightning flash is very high and that it is released in pulses of short duration (10-100 $\mu \mathrm{s})$. The integral of high power over a short period of time is moderate. The capturing of lightning strikes requires the use of a large number of tall towers, which is rather impractical. However, the lightning energy of one average flash may be equivalent to an amount of energy released in the burning of 20 to $30 \mathrm{~kg}$ of oil. The measured value of energy per unit resistance for negative lightning of $10^{5}-10^{8} \mathrm{~A}^{2} \mathrm{~s}$ and an assumed range of effective resistance at the strike point of 10 to $100 \Omega$, we estimate the range of lightning energy at the lightning point to be from $10^{6}$ to $10^{7} \mathrm{~J}$, which is only $10^{-2}-10^{-3}$ of the total energy involved in lightning. If we can somehow download safely the whole energy then it might be of the order of some $10^{9}$ to $10^{10} \mathrm{~J}$.

A single natural lightning pulse of $1.5 \mathrm{GV}$ potential, $1000 \mathrm{~A}$ current and $50 \mu \mathrm{s}$ duration can produce energy of $\left(\mathrm{V} \times \mathrm{I} \times \Delta \mathrm{t}=1.5 \times 10^{9} \times 1000 \times 50 \times 10^{-6} / 3600\right) 21 \mathrm{kWh}$. Considering a normal cloud to ground lightning strike

Pulse duration $=1 \mu \mathrm{s}$

Lightning voltage $=1800 \mathrm{MV}$

Lightning current $=1500 \mathrm{~A}$

Charge rate $=10 \mathrm{C}$

Lightning energy (per $10 \mu \mathrm{s}$ )

$=\mathrm{V} \times \mathrm{I} \times \Delta \mathrm{t}=1.8 \times 10^{9} \times 1.5 \times 10^{3} \times 1 \times 10^{-6}=2.7 \times 10^{6} \mathrm{~J}$

No of $1 \mu$ s intervals in $24 \mathrm{Hrs}=24 \times 60 \times 60 \times 10^{6} / 1=8.64 \times 10^{10}$

Energy delivered in $24 \mathrm{Hrs}=27 \times 10^{6} \times 8.64 \times 10^{10}$

$=2333 \times 10^{15} \mathrm{~J}$

Assuming that two high repetition rate $(=\mathrm{CW})$ lasers artificially trigger lightning phenomena in every $10 \mu \mathrm{s}$ interval in a well synchronized manner then the total energy received on earth may be $2333 \times 10^{15} \mathrm{~J}$. At a conversion rate of $1 \mathrm{kWh}=3.6 \times 10^{6} \mathrm{~J}$ lightning energy become $65 \times 10^{10} \mathrm{kWh}$. The actual energy requirement for a population of 10 Billion (@) $1 \mathrm{kWh} /$ person) is $120 \times 10^{10} \mathrm{kWh}$.

The typical lightning power $\left(\Delta \mathrm{E} / \Delta \mathrm{t}=27 \times 10^{6} / 1 \times 10^{-6}\right)$ is of the order of $27 \times 10^{12} \mathrm{~W}$. Assuming two high repetition rate $(=\mathrm{CW})$ lasers, the power received in $8.64 \times 10^{9}$ intervals each of $10 \mathrm{~s}$ duration is about $23 \times 10^{22}$ Watts. Energy received over $24 \mathrm{Hrs}$ is

Lightning energy delivered in $24 \mathrm{Hrs}$

$=23 \times 10^{22} / 24 \times 3600=26.6 \times 10^{17} \mathrm{~J}$

Lightning energy delivered in $24 \mathrm{Hrs}=$ $26.6 \times 10^{17} / 3.6 \times 10^{6}=74 \times 10^{10} \mathrm{kWh}$

According to the lightning energy calculation by the Phillips Laboratory [107] any single average lightning flash may produce 300 to $3000 \mathrm{kWh}$ of energy. If the process could be repeated at a high repetition rate $(24 \times 60 \times 60 / 200 \mu \mathrm{s}$ $=432 \times 10^{6}$ ) then the total energy received and stored in 24 Hrs could be low as $30 \times 432 \times 10^{6}=13 \times 10^{9}$ to as high as $3000 \times 432 \times 10^{6}=3000 \times 10^{9} \quad \mathrm{kWh}$. This difference may be attributed to use of peak and measured rms values in above calculations. On average one lightning phenomenon consists of two to eight pulses and therefore $432 \times 10^{6}$ intervals were used instead of $8.64 \times 10^{9}$ intervals in the laser triggered single $1 \mu \mathrm{s}$ pulse calculations. At the rate of air breakdown voltage of approximately $30 \mathrm{kV} / \mathrm{cm}$ it takes $3 \times 10^{9}$ volts potential difference to cause lightning between $1 \mathrm{~km}$ height cloud and the earth as assumed in the above calculations. Static electricity breakdown threshold is $10 \mathrm{kV} / \mathrm{cm}$ i.e. three times lesser than normal AC/DC electric potentials therefore above voltage of 3 billion lowers to one billion volts only. More precise calculations may be able to bridge the difference between the two above calculations.

Japanese researchers have been trying since a long time ago to harness natural lightning energy to protect the high voltage transmission system and to produce renewable energy but no apparent success to date. Shindo and Aihara have produced some $2 \mathrm{~m}$ long electric discharges in air using a $\mathrm{CO}_{2}$ laser under laboratory conditions [131]. Researchers at Osaka University, Japan [132-133] succeeded for the first time in 1999 to demonstrate a laser-triggered lightning stroke, enabling lightning to discharge harmlessly to ground with several millions volts at $35 \mathrm{kA}$ current. They used two $\mathrm{CO}_{2}$ lasers giving $20 \mathrm{GW}$ power, $1 \mathrm{~kJ}$ energy emitting $50 \mathrm{~ns}$ pulses. The first beam is focused in a line onto a dielectric target at the top of the tower and a second beam was focused to a two meters long line above the target to guide the stepped leader out of the corona region of the clouds. They also focused a glass laser with $600 \mathrm{~J}$ energy and a $50 \mathrm{~ns}$ pulse onto the target. The fourth harmonic of a Nd:YAG laser with $100 \mathrm{~mJ} /$ pulse at repetition rate of $70 \mathrm{~Hz}$ was also aimed well above the target to provide a soft plasma channel between the target (tower top) and the clouds. According to J-C Diels [134] the use of femtosecond UV laser is preferred since it has the same capability as a $20 \mathrm{GW}$ power at reduced energy levels compared to hundreds of joules of $\mathrm{CO}_{2}$ laser. Rocket-triggered (not laser) lightning experiments are regularly conducted in America and also China to cause artificial lightning. A preliminary report on laser triggered lightning [135] reveals all the initial state of art in 1990's that is still interesting for green horn researchers.

\section{CONCLUSIONS}

Lightning incidences on humans, aircrafts, wind turbines, light rail transits, electric grids, and telecom towers cause huge life and property losses. Electric grid, airplanes and LRTs have relatively well established standards for lightning protection yet wind turbines need new standards. It is estimated over 1.5 billions flashes occur every year and some of them kill 2 to 233 people in each country every year. Average numbers of deaths were higher in past but development in technology and awareness has decreased the number in recent years. US lightning fatalities used to be over 100 per year but modern preventive and protection measures have reduced the frequency 50 per year in 2012 and 13 in first six months of 2013. Several lightning inflicted deaths go unnoted therefore the frequency of fatalities is doubted to be 40 to $50 \%$ higher than reported. Most of lightning incidences impart 7 to $8 \mathrm{~J}$ energy but human damage threshold varies from 10 to50J. It is supposed the positive lightning incidences bearing higher currents can impart more than hazard threshold energy to human body during direct hits or side flashes. There is no safe place during thunderstorm outside therefore "when it roars go 
indoors". If you find no safe place then it is better to crouch on ground rather than standing or trying to seek shelter under tree. Lightning is a powerful natural phenomenon involving thousands of amperes, millions to billions of volts, and trillions to quadrillions of watts. Most electric energy is lost in air during lightning in the form of light, heat, sound and radio waves. Some researchers have attempted to capture lightning energy for human use but none has succeeded to date. Americans hold the best available long-term lightning flash data collected over decades using ground and satellitebased detectors and recorders. Books on lightning physics by Profs. Uman and Golde and publications of Kitagawa and Berger are excellent references to learn secrets of lightning phenomenon.

\section{CONFLICT OF INTEREST}

The authors confirm that this article content has no conflict of interest.

\section{ACKNOWLEDGEMENTS}

Many thanks to Benjamin Franklin, Martin Uman, Phillip Krider and Nobu Kitagawa, William Roeder and others for developing basic understanding of physical principles behind lightning phenomenon and Mary Ann Cooper, Ron Holle, Raul Lopez and others for physiological happenings following lightning strikes.

\section{CONFLICT OF INTEREST}

The authors confirm that this article content has no conflict of interest.

\section{REFERENCES}

[1] Golde. R.H. Lightning. New York: Academic Press 1977.

[2] Bruhac J. How the hero twins found their father, flying with the eagle, racing with the great bear. Mexico: Bridge Water Books 1993.

[3] Franklin B. Experiments and observations on electricity made at Philadelphia. London E Cave 1774.

[4] Keul AG, Freller MM, Himmelbauer R, Hlzer B, Isak Barbara. Lightning knowledge and folk beliefs in Austria. J Light Res 2009; 1:28-35.

[5] Dev P. Lightning protection analysis of light rail transit DC overhead contact system. Proceedings of IEEE Conf. I\&CPS 2005; pp. 159-69.

[6] Behnke SA, Thomas RJ, Stephen R, et al. Observations of volcanic lightning during the 2009 eruption of Redoubt Volcano. J Volcanol Geothermal Res 2011; Available from http://www.giseis.alaska.ed u/Input/steve/PUBS/Behnke2012.pdf

[7] VanDevender JP. Ball lightning: new physics, new energy source, or just entertainment? ICOPS. Plasma Sci 2006; 475.

[8] Qureshi N. Indirect lightning strike via telephone wire. Injury 1995; 26: 629.

[9] Ostgaard N, Gjesteland T, Carlson BE, et al. Simultaneous observations of optical lightning and terrestrial gamma ray flash from space. Geophys Res Lett 2013.

[10] Chubenko AP, Karashtin AN, Ryabov VA, et al. Energy spectrum of lightning gamma emission, Phys Lett A 2009; 373 (33): 29532958.

[11] Dagmar B, Svatopluk C, Libor J. Chemical consequences of laserinduced breakdown in molecular gases. Prog Quantum Electron 2006; 30: 75-88.

[12] Uman MA. Everything you always wanted to know about lightning but were afraid to ask. Saturday Rev 1972; pp. 36-41.

[13] Rakov VA, Uman MA. Origin of lightning electric field signatures showing two return stroke waveforms separated in time by a millisecond or less. J Geophys Res 1994; 99(4): 1857-65.

[14] Bils JR, Thomson EM, Uman MA, Mackerras D. Electric field pulses in close lightning cloud flashes. J Geophys Res 1988; 93: (15) 933-40.
[15] Kitagawa N,Brook M. A comparison of intra cloud and cloud-toground lightning discharges. J Geophys Res 1960; 65: 1189-201.

[16] Ogawa T, Brook M. The mechanism of the intracloud lightning discharge. J Geophys Res1964; 69: 5141-50.

[17] Rakov VA, Thottappillil R, Uman MA. On the empirical formula of Willett et al. relating lightning return-stroke peak current and peak electric field. J Geophys Res 1992; 97(11): 527-33.

[18] Uman MA. The lightning discharge. San Diego: Academic Press 1987.

[19] Rubinstein M, Uman MA. Methods for calculating the electromagnetic fields from a known source distribution: Application to lightning. IEEE Trans on Electromagc Compat 1989; 31(2): 183-9.

[20] Master MJ, Uman MA, Lin YT, Standler RB. Calculations of lightning return stroke electric and magnetic fields above ground. J Geophys Res 1981; 86: 12127-12132.

[21] Saba MMF, Ballarotti MG. Negative cloud-to-ground lightning properties from high-speed video observations. J Geophys Res 2006; 111.

[22] Torres H, Trujillo O, Amórtegui F, et al. Design construction of three devices to directly measure lightning parameters. Proceedings of $10^{\text {th }}$ ISH IEE London 1999.

[23] Zhou E, Lu W, Zhang Y, Zhu B, Zheng D, Zhang Y. Correlation analysis between the channel current and luminosity of initial continuous and continuing current processes in an artificially triggered lightning flash. Atmos Res 2013; 129-130: 79-89

[24] Campos LZS, Saba MMF, Warner TA, Pinto OJ, Krider EP, Orville RE. High-speed video observations of natural cloud-toground lightning leaders - A statistical analysis. Atmos Res 2013: corrected proof online available.

[25] Berger K, Anderson RB, Kröninger H. Parameters of lightning flashes. Electra 1975; 41: 23-37.

[26] Loeb LB. The mechanisms of stepped and dart leader in cloud-toground lightning strokes. J Geophys Res 1966; 71: 4711-21.

[27] Ogawa T, Brook M. The mechanism of intra cloud lightning discharge. J Geophys Res 1964; 69: 5140-50.

[28] Weidman C, Boye A, Crowell L. Lightning spectra in the 850-1400 $\mathrm{nm}$, near infrared, region. J Geophys Res 1989; 94: 13249-57.

[29] Orville RE, Lala GG, Idone VP. Daylight time-resolved photographs of lightning. Science 1978; 201: 59-61.

[30] Orville RE. Peak-current variations of lightning return strokes as a function of latitude. Nature 1990; 343: 149-51.

[31] Rakov VA, Uman MA. Long continuing current in negative lightning ground flashes. J Geophys Res 1990; 95: 5455-70.

[32] Chowdhuri P. Parameters of lightning strokes and their effects on power systems. TDC 2001; 2: 1047-51.

[33] Field PR, Hand WH, Capelluti G, et al. Hail threat standardization 2008; European Aviation Safety Agency: RP EASA.

[34] NASA. Staying safe in lightning alley 2007.

[35] Available from http://www.stem-works.com/external/article/308 [cited 2013, July]

[36] Available from www.lightningstrikes.noaa.gov/statistics.htm [cited 2013, July].

[37] Edward JP. What happens when lightning strikes an airplane? Sci Am 2001: 1-2.

[38] Jie L, Sun D-D. Analysis on Lightning Strike Damages to Optical Fiber Composite Overhead Ground Wire Industrial and Information Systems. IIS 2009: pp. 39-44.

[39] Dev P. Light rail transit Dc traction power system surge overvoltage protection. IEEE Trans Ind App 2002; 38: 21-5.

[40] Dalziel CF. Threshold 60-cycle fibrillating currents. AIEE Trans Power Appl Syst 1960; 79(4): 667-73.

[41] Ossypka P. Messtechnische Untersuchungen .uber stromst.arke Einwirkungsdauer und Stromweg bei elektrischen Wechselstromunf.allen an Mensch und Tier. Elektromedizin 1963; 8:153-179.

[42] Szczerbinski M. Lightning hazards and risks to humans: some case studies. J Electrostat 2003; 59: 15-23.

[43] Berger K. Zum Problem des Personenblitzsch. Bull Schweiz. Elektrotech 1971; 62: 397-9.

[44] Richard H. Mitigating lightning hazards. Sci Tech Rev 1996.

[45] Chai JC, Heritage HA, Wilson HZ. Lightning energy absorption in humans and personal safety. Proceedings of the 1994 International Aerospace and Ground Conference on Lightning and Static Electricity. Mannheim 1994.

[46] Marcus OD, Robert AD. Lightning, transient \& high frequency impact on materials such as corrugated tubing. Frontiers of Power. Oklahoma State University 2008. 
[47] Elin F, Svein TH. Small scale arc fault testing in air. CIRED 2009; 0688 .

[48] Rakov VA, Uman MA. Lightning: Physics and effects 2003.

[49] Jakke M, Eero K, Niko P, Antti M, Tapio T. Attachment of natural lightning flashes to trees: Preliminary statistical characteristics. J Light Res 2009; 1: 9-21.

[50] Taylor AR. Lightning damage to forest trees in Montana. Weatherwise 1964; 17(2): 61-5.

[51] Darveniza M, Zhou Y. Lightning-initiated fires: Energy absorbed by fibrous materials from impulse current arcs. J Geophys Res 1994; 99(10): 663-70.

[52] Saraoja EK. Lightning earths. In: Golde RH, Ed. Lightning, Lightning Protection. New York: Academic Press 1977; vol. 2.

[53] Henderson AR. Laser safety - Hazards in perspectives. Proc. International Conf. on lasers in manufacturing. UK 1983.

[54] Bazelyan EM, Aleksandrov NL, Raizer YP, Konchakov AM. The effect of air density on atmospheric electric fields required for lightning initiation from a long airborne object. Atmos Res 2007; 86: 126-38.

[55] Fisher FA, Plummer JA, Peraia RA. Lightning Technologies 2004.

[56] Sweers G, Birch B, Gockcen J. Lightning strikes: protection, inspection and repair. AERO Quarterly. GTR 2004; 12:19-28.

[57] Fisher, FA, Plumer JA. Lightning Protection of Aircra Fort Pittsfield. MA: Lightning Technologies Inc 1990.

[58] Majkner R. Overview-Lightning protection of aircraft and avionics. Proceedings of LI IEEE EMC, USA. 14 October 2003.

[59] Uman MA, Rakov VA. The interaction of lightning with airborne vehicles. Prog Aero propul Sci 2003; 39: 61-81.

[60] Available from http://www.kentonline.co.uk/kentonline/news/201 2/november/5/lightning_strike.aspx. [Cited 2013, July 26].

[61] Available from Boja Air: http://en.wikipedia.org/wiki/Bhoja_Air_ Flight_213. [Cited 2013, July 10].

[62] Available from Wikipedia http://en.wikipedia.org/wiki/Lightning strike. [Cited 2013, July 26].

[63] Romero C, Mediano A, Rubinstein A, et al. Measurement of lightning currents using a combination of Rogowski coils and BDot sensors. J Light Res 2012; 4: 71-4.

[64] Ramzan M. A comparative study of current transducers. MS Thesis. UPM 2002.

[65] Brian M, Dan U, Carla P, Brenda J, Jennifer Y, Kelsey S. Striking back: An assessment of lightning related fatality and injury risk in Canada. Final Technical Report 2006.

[66] Leutron. Lightning and surge protection of wind turbines. Available from www.leutron.de [citied, June 2013]

[67] Jiang JL, Chang HC, Kuo CC. Analysis of transient energy affection for wind farm under lightning. Energy 2012; 48(1): 292-7

[68] Shigeru Y. Lightning protection of wind turbine blades. Elect Power Sys Res 2013; 94: 3-9.

[69] Jiang JL, Chang HC, Kuo CC, Huang CK. Transient over voltage phenomena on the control system of wind turbines due to lightning strike. Renewable Energy 2013; 57: 181-189.

[70] Rodrigues RB, Mendes VMF, Catalão JPS. Protection of wind energy systems against the indirect effects of lightning. Renewable Energy 2011; 36(11): 2888-96.

[71] Gewehr HW. Lightning Protection for Composite Rotor Blades. Conference Proceeding of the American Wind Energy Association Washington; USA 1980.

[72] Dodd, CW, McCalla, TM, Smith, J.G. Design Considerations for Lightning Protection of Wind Turbines. Sixth Biennial Wind Energy Conference and Workshop Boulder. American Solar Energy Society 1983.

[73] Cotton I, Jenkins N, Haigh S, Hancock M, Hatziagyriou, Jaquemotte P. Lightning Protection of Wind Turbines - A Designers Guide to Best Practices. Manchester, UK: UMIST 1999.

[74] Available from http://www.fkl.fi/en/material/publications/Publicati ons/Wind_turbine_damage_prevention_2013.pdf [cited 2013, July]

[75] Kern A, Krichel $\overline{\mathrm{F}}$. Considerations about the lightning protection systems of mains independent renewable energy hybrid systemspractical experiences. J Electrostat 2004; 50: 257-63.

[76] Ukar O, Zamora I. Wind farm grounding system design for transient currents. Renewable Energy 2011; 36: 2004-20.

[77] Yokoyama S. Lightning protection of wind turbines. Electric Power Sys Res 2013; 94: 3-9.

[78] Bertelsen K, Eichsen HV, Skov JMVR, Madsen SF. Application of numerical methods to determine lightning attachment points on wind turbine. Proc Int. Conf. Lightning and Static Electricity, France 2001.

[79] Rupp C. Fundamentals and Advanced Topics in Wind Power, Intech Web 2011; 65-88.

[80] Ebrahim AB, Mohammad EMR, Mansour HAR. Analysis and suppression of back flow lightning surges in onshore wind farms. J Light Res 2011; 3: 1-9.

[81] Hileman AR. Insulation coordination for power system. New York: Marcel \& Dekker 1999.

[82] Pham KD, Thomas RS, Stinger WE. Light Rail Electrification: Operational and Safety Considerations for Light Rail DC Traction Electrification System Design. 9th National Light Rail Transit Conference Transportation Research Circular E- 2003: Portland.

[83] Pham, KD, Thomas RS, Stinger WE. Analysis of Stray Current, Track-to-Earth Potentials, and Substation Negative Grounding in DC Traction Electrification Systems. Proc IEEE/ASME Joint Rail Conference, 2000.

[84] IEEE Committee Report. A simplified method of estimating lightning performance of transmission lines. IEEE Trans Power Apparatus Sys 1985; 104: 919-32.

[85] Dev P. Lightning Protection Analysis of Light Rail Transient DC Overhead Contact System. Industrial and commercial Power System Technical Conference 2005; NY. 8-12 May.

[86] Zhou QB, Du Y. Analysis of lightning transients in a DC traction power system of electrified railway using EMTP. IEEE Conf, 2006: pp. 1831-1835.

[87] Draft IEEE standard for traction power rectifier transformers for substation applications up to $1500 \mathrm{~V}$ DC nominal output 2011 IEEE P1653.1 ${ }^{\mathrm{TM}} / \mathrm{D} 7$.

[88] Ren X, Fu Z, Yan N, Sun W. Analysis and experimental investigation of direct lightning protection for floating roof oil tanks. Electric Power Sys Res 2013; 94: 134-9.

[89] Kijima H, Jakato K, Murakwa K. Lightning protection of gas pipelines installed under the ground. Int J Sys App Eng Devel 2011; 5: 1-5

[90] Bhumkittipich K, Topradith B, Suwanasri T. Analysis of lightning phenomenon for underground petroleum pipelines systems. Energy Proc 2013; 34: 148-58.

[91] Emyliah N. Simulation study on lightning effects to $132 \mathrm{kV}$ underground cable, Universiti Knotogmi Ataysa 2011.

[92] Andreotti A, Pierno A, Rakov VA. An analytical approach to calculation of lightning induced voltages on overhead lines in case of lossy ground-Part 1: Model Development. IEEE Trans Power Deliv 2013; 28: 1213-23.

[93] Zhang X, He J. Lightning overvoltage suppression to UHV power transformer by ferromagnetic ring. Electric Power Syst Res 2013; 94: 122-8.

[94] Sarajcev P, Vasilij J, Goic R. Monte Carlo analysis of wind farm surge arresters risk of failure due to lightning surges. Renewable Ener 2013; 57: 626-34.

[95] Zaddam A, Degauque P. Current and voltage induced on telecommunication cable by a lightning return stroke. In Lightning Electromagnetics, Gardner RI, Ed. New York Hemisphere 1990: pp. $377-400$.

[96] Diendorfer G. Induced voltage on an overhead line due to nearby lightning. IEEE Trans Electromag Compat 1990; 32: 292-9.

[97] Hoidalen HK, Slebtak J, Henriksen T. Ground effects on induced voltages from nearby lightning. IEEE Trans Electromag Compat 1997; 39: 269-78.

[98] Rubinstein M. An approximate formula for the calculation of the horizontal electric field from lightning at close, intermediate and long range. IEEE Trans Electromag Compat 1996; 38: 531-5.

[99] Cooray V, Cooray C, Andrews CJ. Lightning caused inhjuries in humans. J Electrostat 2007; 65: 386-94.

[100] Newman NM, Stahmann JR, Robb JD, Lewis EA, Martin SG, Zinn SV. Triggered lightning strokes at very close range, J Geophys Res 1967; 72: 4761-4.

[101] Fieux R, Gary C, Hubert P. Artificially Triggered Lightning above Land. Nature 1975; 257: 212-4.

[102] Fieux R, Gary C, Hubert P. Research on artificially triggered lightning in France. IEEE Trans Power Apparatus Syst 1978; 97: 725-33.

[103] Hubert P, Laroche P, Berard AE, Barret L. Triggered lightning in New Mexico. J Geophys Res 1984; 86: 2511-21. 
[104] Horii K, Wada A, Nakamura K, Yoda M, Kawasaki Z, Sirait KT, Soekarto J, Sunato AM. Experiments of rocket triggered lightning in Indonesia. IEEE Japan 1990; 110-B: 1068.

[105] Liu X, Wang C, Zhang Y, Xiao Q, Zhou Z, Guo C. Experiments of artificially triggered lightning in China. J Geophys Res Atmos 1994; 99: 10727-31.

[106] Wang D, Ushio T, Kawasaki Z-I, et al. A possible way to trigger lightning using a laser. J Atmos Terrestrial Phys 1995; 57: 459-66

[107] Zhang Y, Yang S, Lu W, et al. Experiments of artificially triggered lightning and its application in Conghua, Guangdong, China. Atmos Res 2013. Corrected proof available online.

[108] Kozima MA. A brief history of laser guided lightning discharge models and experiments. Project Report No. PL-TR-94-2193, July 1994.

[109] Mazur V, Ruhnke LH. Common physical processes in natural and artificially triggered lightning. J Geophys Res Atmos 1993; 12: 12913-30.

[110] Diels J, Zhao XM, Wang CY. Discharge of electrically charged clouds. Phillips Laboratory 1992; PL-TR-92-2266 AD A263213.

[111] Kozima M, Wacker R, Gjone K. High power microwave weaponry. USAFA Physics 362 Project 1994.

[112] Barnes AA, Berthel RO. A survey of laser lightning rod techniques, International Aerospace \& Ground Conference on Lightning and Static Electricity, Cocoa Beach, FL.16-19 April 1991.

[113] Shindo T, Aihara Y, Miki M, Sizuki T. Model experiments of laser triggered lightning. IEEE Trans PD 1993; 8: 311-7.

[114] Kasparian J, Rodriguez M, Mejean G, et al. White Light Filaments for Atmospheric Analysis. Science 2003; 61(301): 5629.

[115] Shindo T, Aihara Y. A shielding theory for upward lightning, IEEE Trans Power Deliv 1993; 8: 318-24.

[116] Durand M, Houard A, Prade B, et al. Kilometer range filamentation: effects of filaments on transparent and nontransparent materials at long distances," in CLEO:2011 - Laser Applications to Photonic Applications, OSA Technical Digest; CThFF3.

[117] Khan N, Norman M, Ishak A, Yeak J. Laser-triggered lightning discharge. N J Phys 2002; 4: 61.1-61.20

[118] Available from: http://www.newscientist.com/article/dn13669-shoot ing-clouds-with-lasers-triggers-electrical-discharge.html\#.UfK7rNJH KmQ [cited 2013, July]

[119] Khan N, Saleem Z, Abas N. Photon fired power plants. Lasers Eng 2008; 18(5-6): 383-401.

[120] Zvorykin VD, Ionin AA, Levchenko AO, et al. Effects of picosecond terawatt UV laser beam filamentation and a repetitive pulse train on creation of prolonged plasma channels in atmospheric air. Nuclear Instruments and Methods in Physics Research Section B: Beam Interactions with Materials and Atoms 2013; In Press corrected proof available online.

[121] Kasparian J, Wolf JP, Physics and applications of atmospheric nonlinear optics and filamentation. Optics Express 2008; 16: 466.

[122] Comtois D ,Pepin H, Vidal F, Rizk FAM, Chien CY, Johnston TW, Kieffer JC, Fontaine B, Martin F, Potvin C, Couture P, Mercure HP, Bondiou CA, Lalande P, Gallimberti I. Triggering and Guiding of an Upward Positive Leader From a Ground Rod With an Ultrashort Laser Pulse-I: Experimental results. IEEE Trans on Plasma Sci 2003; 31:377.

[123] Rodrigues P, Schillinger H, Niedermeier S, et al. Remote sensing of the atmosphere using ultrashort laser pulses. Appl Phys B 2002; 71: 573-80.

[124] La Fontaine B, Comtois D, Chien CY, et al. Guiding large-spark discharges with ultrashort pulse laser filaments. J Appl Phys 2000; 88: 610-5.

[125] Forestier B, Houard A, Reve I, et al. Triggering, guiding and deviation of long air spark discharges with femtosecond laser filament. AIP Adv 2012; 2: 012151.

[126] Pepin H, Comtois D, Vidal F, et al. Triggering and guiding highvoltage large-scale leader discharges with sub-joule ultrashort laser pulses. Phys Plasmas 2001; 8: 2532.

[127] Víctor M, Manuel A, José LT, Joan M, David R, Glòria S, Daniel A. Features of electrical discharges in air triggered by laser. J Electrostat 2009; 67: 301-6.

[128] Available from http://hyperphysics.phy-astr.gsu.edu/hbase/electric/ lightning2.html. [Cited 2013, July].

[129] Helman DS. Catching lightning for alternative energy. Renewable Energy 2011; 36:1311-1314.

[130] Farriz MB, Herman JM, Jidin A, Zulkurnain AM. A new source of renewable en energy from lightning stroke: A small scale system. IEEE Int. Conf on Power Electronics 2010; 1490-3.

[131] Shindo T, Yoshinori A, Miki M, Toshio S. Model experiments of laser-triggered lightning. IEEE Trans Power Deliv 1994; 8: 1.

[132] Yvonne P. Laser-triggered lightning discharges harmlessly. OEReports 1999; 187.

[133] Uchida S, Shimada Y, Yasuda H, Motokoshi S, Yamanaka C, Yamanaka T, Kawasaki Z, Tsubakimoto Z. Laser-triggered lightning in field experiments. J Opt Tech 1999; 66(3): 199-202.

[134] Rambo P. Laser-induced lightning. PhD Thesis University of New Mexico 2000.

[135] Wang D, Kawasaki ZI, Matsuura K, et al. A preliminary study on laser-triggered lightning. J Geophy Res Atmos 1994.

(C) Kalair et al.; Licensee Bentham Open.

This is an open access article licensed under the terms of the Creative Commons Attribution Non-Commercial License (http://creativecommons.org/licenses/by-nc/3.0/) which permits unrestricted, non-commercial use, distribution and reproduction in any medium, provided the work is properly cited. 